Andrzej Laskowski

Uniwersytet Ekonomiczny w Krakowie

\title{
Zespół witraży w kościele parafialnym w Mszance koło Gorlic. Przyczynek do dziejów witrażownictwa krakowskiego 2. ćwierci XX wieku
}

W badaniach nad sztuką, przy ustalaniu istotnych faktów dotyczących dorobku różnych twórców czy dziejów warsztatów wykonujących dzieła sztuki, istotne znaczenie mają nie tylko łatwo na ogół dostępne źródła znajdujące się w artystycznych centrach, ale także te, które kryją się na prowincji, często zapomniane czy wręcz lekceważone. Szczególnego znaczenia źródła takie nabierają w odniesieniu do sztuki witrażowej, gdzie podstawowa faktografia wciąż posiada poważne luki, wiele zakładowych archiwów uległo zniszczeniu lub rozproszeniu, wypadki dziejowe nierzadko pozbawiły nas najważniejszych źródeł, jakimi dla historyka sztuki są same dzieła sztuki, a wszystko to ma miejsce przy niezwykle obfitej (a przez to trudnej do całościowego uchwycenia) produkcji zakładów witrażowych, w znakomitej większości przeznaczonej dla zleceniodawców na prowincji.

Z takimi źródłami mamy do czynienia w położonej pod Gorlicami Mszance, gdzie dzięki podziwu godnej dbałości miejscowych kapłanów w niezwykłym porządku zachowało się archiwum parafialne, a w nim m.in. obszerna korespondencja z krakowskimi zakładami witrażowymi, pochodząca z lat 30. i 40. XX wieku. Jak łatwo ocenić po jej lekturze, waga tego znaleziska znacząco przewyższa poziom artystyczny tematu owej korespondencji, jakim są witraże zachowane do dzisiaj w miejscowym kościele parafialnym. Warto poświęcić im nieco uwagi, gdyż nie były one dotychczas przedmiotem zainteresowania badaczy ${ }^{1}$.

\footnotetext{
${ }^{1}$ Witraże w Mszance nie zostały odnotowane w literaturze przedmiotu. Po raz pierwszy zwrócono na nie uwagę przy okazji prezentacji zatytułowanej Nie tylko Żeleński. Witraże kościołów diecezji tarnowskiej w okresie międzywojennym, przedstawionej przez autora niniejszego tekstu na sesji pt. Nie tylko art déco. Sztuka witrażowa $w$ dwudziestoleciu międzywojennym, zorganizowanej w dniach 6-8 października 2011 roku w Rzeszowie.
} 


\section{Świątynia i jej witraże}

Kościół pw. Świętych Apostołów Piotra i Pawła w Mszance (il. 1) został wzniesiony w latach 1938-1940 według projektu Edwarda Okonia, pod kierownictwem Józefa Wójcika, a jego poświęcenie odbyło się 22 grudnia $1940 \mathrm{roku}^{2}$. Parafię erygował tu dopiero bp Jan Stepa w 1950 roku, wydzielając ją z parafii Moszczenica. Również po wojnie przed kościołem wzniesiona została wolno stojąca dzwonnica, dopełniająca miejscowy zespół kościelny.

Kościół został usytuowany w centrum wsi, na płaskowyżu, z którego roztacza się interesujący widok na położone niżej tereny sąsiednich wiosek. Jego front został skierowany ku głównej drodze wiodącej przez Mszankę i poprzedzony dziedzińcem, zamkniętym od prawej strony żelbetową, pomalowaną na biało dzwonnicą i ciągnącym się wzdłuż drogi metalowym ogrodzeniem o kamiennej podmurówce i ceglanych słupach.

Plan świątyni jest bardzo klarowny, bazuje na formie krzyża łacińskiego. Węższemu od jednonawowego korpusu prezbiterium towarzyszą transept, zakrystia i niewielka boczna kruchta. Konsekwencją takiego planu jest zwarta bryła kościoła, w której nad ścianami z czerwonej cegły, przeprutymi półkoliście zamkniętymi oknami, wznoszą się kryte blachą dwuspadowe dachy, zakończone trójkątnymi ścianami szczytowymi, a w miejscu zbiegu obu kalenic wieżyczką na sygnaturkę. Elewacje pozbawione są zasadniczo detalu, który łączyłby budynek z jakąkolwiek formacją stylową, a ukształtowany z cegieł wydatny gzyms koronujący ma jedynie charakter spinającego całość budowli horyzontalnego akcentu. Potraktowana na tym tle nieco staranniej fasada wyróżnia się zastosowaniem przetworzonego motywu łuku triumfalnego w przyziemiu, użyciem identyfikującego funkcję budowli krzyża (posadowionego na tle otworu okiennego nad wejściem) oraz zwieńczeniem całości w formie dwukondygnacyjnego szczytu, dekorowanego otworami okiennymi, wolutowymi spływami i ażurowym, metalowym krzyżem.

Wnętrze świątyni jest niewielkie, ale klarowne w swej strukturze, pozbawione nadmiaru detali architektonicznych, przesklepione. Szczególną uwagę zwraca sklepienie w korpusie nawowym, imitujące kolebkę, wsparte po obu stronach na silnie sfazowanym gzymsie, poprzerywanym w miejscach lokalizacji lunet z otworami okiennymi. Usytuowany bezpośrednio za głównym wejściem chór muzyczny, wsparty na dwóch kolumnach w porządku kompozytowym i zwieńczony balustradą

\footnotetext{
${ }^{2}$ Podstawowe informacje o tym kościele podaję za: M. Kornecki, Kościoły diecezji tarnowskiej, „Rocznik Diecezji Tarnowskiej” 1972, s. 204-205. O jego twórcy, absolwencie Politechniki Lwowskiej Edwardzie Okoniu (1884-1955), i jego działalności w Tarnowie pisze nieco S. Potępa, Architektura Tarnowa w latach 1772-1939, [w:] Przewodnik po Tarnowie, red. S. Potępa, Tarnów 1982, s. 159-161. Nad głównym wejściem do kościoła widnieje umieszczony w okrągłej wnęce ryty napis „BOGU NA CHWAŁĘ RP 1938", który wraz z archiwalnymi zdjęciami zachowanymi w parafialnym archiwum świadczy o znacznym zaawansowaniu robót budowlanych przy świątyni już w roku 1938.
} 
z tralkami, stanowi w zasadzie jedyny - obok wspomnianego gzymsu - historyzujący element wnętrza. Wnętrze to doświetlają smukłe, zakończone półkoliście okna (il. 2).

Zasadniczo mamy tu zatem do czynienia $\mathrm{z}$ architekturą zasługującą na określenie „zmodernizowany historyzm”, gdzie owo modernizowanie ukierunkowane jest na maksymalne upraszczanie historycznych form i detali architektonicznych, a zastosowany materiał budowlany nie niesie ze sobą konotacji stylowych.

Ważnym dopełnieniem pomalowanego na biało wnętrza świątyni są witraże. Najbardziej dekoracyjny charakter posiadają te zlokalizowane w prezbiterium, flankujące ołtarz główny (il. 3). Na witrażu po lewej stronie umieszczono wizerunek stojącego wśród obłoków i trzymającego w ręku pęk kluczy św. Piotra, któremu towarzyszą umieszczone na szarfach napisy. U góry jest to inwokacja: „ŚWIĘTY PIOTRZE MÓDL SIE ZA NAMI”, a u dołu napis fundacyjny z datą: „FUNDACJA / R.P. 1939 / TADEUSZ I KAROLINA JANASOWIE" (il. 4)³. Z kolei na witrażu po prawej stronie umieszczono wizerunek św. Zofii z trzema córkami. Święta, ubrana w bogaty płaszcz, stoi z rozłożonymi w modlitewnym geście rękoma na tle zielonej łąki, a przed nią siedzą w przyklęku trzy córki, trzymając narzędzia swej męki. Na dwóch szarfach, o układzie i treści podobnych do tych z poprzedniego witraża, znalazły się napisy: inwokacyjny u góry i fundacyjny u dołu, z których dowiadujemy się, iż o szczególną łaskę św. Zofii proszą Franciszek i Zofia Gubałowie, fundujący ten witraż w 1939 roku (il. 5).

Witraże w ścianach bocznych korpusu nawowego oraz w ścianach zamykających ramiona transeptu (w obu przypadkach po dwa z każdej strony) wykonane zostały według wspólnego schematu kompozycyjnego: ich centrum stanowi okrągły medalion z postacią ukazaną w popiersiu, obwiedziony prostą, zieloną (wewnątrz) i niebieską (po zewnętrznej) bordiurą; jego tło stanowi geometryczna kompozycja w ukośną kratę, wykonana z jasnego szkła, w strefie pod medalionami usytuowano błękitne szyby o kształcie ustawionego pod kątem $45^{\circ}$ kwadratu ze ściętymi dwoma narożami, wypełnione napisami fundacyjnymi i datą roczną dokonania fundacji, każdorazowo określoną jako rok 1939. Tak opracowaną całość ujmują znów proste bordiury o kolorach i w układzie jak wokół medalionów. W tak skomponowanych oknach znajdują się takie oto wizerunki, ufundowane przez następujących dobrodziejów (poczynając każdorazowo od wejścia głównego ku prezbiterium): po stronie północnej - Matka Boska Niepokalanie Poczęta (Stanisław i Waleria Piecuchowie), Święta Rodzina (Wiktoria Gubałowa i Katarzyna Gryzikowa) (il. 6), św. Stanistaw Kostka (Koło Młodzieży Ludowej w Mszance), Najświętsze Serce Pana Jezusa (Kazimierz i Barbara Ryczkowie); po stronie południowej - św. Zofia (Piotr

\footnotetext{
${ }^{3}$ Dolna część tego witraża została zrekonstruowana po II wojnie światowej w zakładzie S. G. Żeleński, o czym wspominam dalej.

${ }^{4}$ Wizerunek św. Zofii, której towarzyszą jako atrybuty trzy symbole odnoszące się do jej trzech córek (Wiara, Nadzieja, Miłość), ukazuje kobietę w królewskim stroju, z koroną na głowie. Sugeruje to, jak się wydaje, połączenie tradycji przedstawieniowej świętej o tym imieniu z królową Polski Zofią
} 
i Zofia Piecuchowie) (il. 7), Matka Boska Nieustajacej Pomocy (Koło Gospodyń w Mszance), św. Teresa (Wójcikowie, Kucharczykowie, Śliwowie i Wójtowiczowie) (il. 8) i Serce Marii (Sekułowie, Janikowie i Wszołkowie) (il. 9). Na dwóch spośród wymienionych witraży (usytuowanych w obu ramionach transeptu, bliżej wejścia do świątyni), znalazły się - w lewym dolnym rogu - sygnatury wykonawcy witraży w brzmieniu: „Wykonał: / M. Romańczyk / Kraków, Św. Jana 30” (il. 10).

Do zespołu tego należą jeszcze dwa niewielkie okrągłe witraże znajdujące się po bokach głównego wejścia do kościoła, dekorowane umieszczonymi w centrum monogramami (IHS po lewej-il. 11, i MARIA po prawej stronie), otoczonymi promieniście skomponowanymi przeołowieniami.

Elementami dodanymi później są natomiast pozostałe przeszklenia: dwubarwne, różnofakturowe szyby w oknie zakrystii, wielobarwne przeszklenie wypełniające półkoliste nadświetle nad wejściem do świątyni i błękitny krzyż równoramienny w oculusie znajdującym się powyżej, na osi głównej fasady.

\section{Przebieg procesu inwestycyjnego i późniejszych napraw}

Proces inwestycyjny w Mszance, który w odniesieniu do witraży zamknął się w roku 1939, odtworzyć można dzięki materiałom archiwalnym. Stroną zamawiającą witraże był Komitet Budowy Kościoła, który 24 lutego otrzymał pisemną ofertę z zakładu Maksymiliana Romańczyka, podającą koszt wykonania różnych rodzajów oszkleń ${ }^{5}$. 8 marca z firmy tej wysłano zawiadomienie, iż podjęto już pracę nad szkicami witraży do Mszanki i że przyjazd pełnomocnika firmy zostanie zapowiedziany ${ }^{6}$. Istotnie, 13 marca firma przekazała pisemnie informację, iż 15 marca przyśle do Mszanki swego przedstawiciela, Ludwika Olejarza, w celu zawarcia umowy, pobrania zadatku i okazania szkiców do planowanych oszkleń celem dokonania wyboru motywów przez stronę zamawiającą. Ta ostatnia miała odebrać Olejarza ze stacji kolejowej w Woli Łużańskiej? Wizyta niechybnie doszła do skutku, bowiem 15 marca zawarto umowę pomiędzy

Holszańską (ok. 1405-1461), czwartą i ostatnią żoną Władysława Jagiełły, inicjatorką pierwszego thumaczenia Biblii na język polski.

${ }^{5}$ Archiwum Parafialne w Mszance [dalej: APM], pismo (oferta) z 24 lutego 1939. Jak wynika z oferty, zakład spodziewał się zlecenia na oszklenie 16 okien o wymiarach 290x120 cm każde. To oraz fakt, iż oferta była skierowana do Zarządu Komitetu Budowy Kościoła w Mszance świadczy, iż była to odpowiedź na zapytanie komitetu, które zawierać musiało konkretne dane co do przyszłego zlecenia. Na temat tego zapytania nic nie wiadomo; niewykluczone, iż było kierowane także do innych firm. Nie znamy powodów, dla których wysłano je do firmy Romańczyka. W ofercie zaznaczono, iż podane koszty obejmują obróbki ślusarskie i montaż, natomiast nie uwzględniają wzniesienia rusztowań, prac murarskich, przewozu z najbliższej stacji kolejowej oraz utrzymania i mieszkania dla montera. Oczekiwano 50 proc. zaliczki. Deklarowano możliwość nadesłania szkiców okien.

${ }^{6} \mathrm{APM}$, karta pocztowa z 8 marca 1939.

${ }^{7}$ APM, pismo z 13 marca 1939. 
Komitetem Budowy Kościoła w Mszance a zakładem Maksymiliana Romańczyka (il. 12), mocą której Romańczyk zobowiązał się wykonać do 25 czerwca - „ze szkła antycznego i katedralnego kolorowego" - 2 witraże figuralne (ze św. Piotrem i św. Zofią) w cenie po 300 zł każdy, 8 witraży geometrycznych po 140 zł każdy i dwa medaliony o średnicy $65 \mathrm{~cm}$ (ze św. Stanisławem Kostką i Najświętszym Sercem Pana Jezusa) po 75 zł każdy. W umowie znalazło się również zobowiązanie firmy, iż gratisowo wykona ona dwa małe okna geometryczne o średnicy $90 \mathrm{~cm}^{8}$; powtórzono też zastrzeżenia zawarte wcześniej w ofercie. Całkowita wartość zlecenia została określona na kwotę 1870 zł. Tego samego dnia przedstawiciel firmy otrzymał od komitetu tytułem zaliczki $270 \mathrm{zl}^{9}$.

Z pisma wysłanego 17 marca dowiadujemy się, iż przedstawiciel zakładu Romańczyka zapomniał zabrać z Mszanki kartkę, na której widniała treść napisów, jakie miały być umieszczone na witrażach ze św. Piotrem i św. Zofią. Prosząc o ich nadesłanie do 15 kwietnia „równocześnie z dalszymi zamówieniami na medaljony czy emblematy", przypomniał, iż do końca marca komitet winien uiścić pozostałą do zapłaty część zaliczki, ustalonej w wysokości 50 proc. wartości zlecenia ${ }^{10}$. Odpowiedź z Mszanki sformułowana została 3 kwietnia ${ }^{11}$. Podano w niej nazwiska fundatorów poszczególnych okien i tematy spodziewanych dodatkowych przedstawień na medalionach, zasadniczo zgodne z tym, co znajduje się do dzisiaj w oknach świątyni ${ }^{12}$. Ze spisu tego wynika, iż udało się znaleźć kolejnych chętnych, aby pozostałe 6 okien, w umowie określonych jako geometryczne, zostało jednak wzbogacone o figuralne medaliony. Równocześnie komitet prosił o wycenę witraży do okrągłych okien pod chórem, które gotów był zamówić, gdyby podana przez firmę cena była przystępna ${ }^{13}$. Uspokajał też Romańczyka w kwestiach finansowych: „pieniądze na okna ściągamy i przeszlemy Szanownej Firmie do 15. IV b.r.”. Jak

${ }^{8}$ APM, umowa z 15 marca 1939. To ostatnie zobowiązanie, zapisane innym kolorem atramentu, zostało niewątpliwie dodane później.

${ }^{9}$ APM, potwierdzenie z 15 marca 1939.

${ }^{10}$ APM, pismo z 17 marca 1939. Taka właśnie wysokość zaliczki była sygnalizowana przez zakład w ofercie z 24 lutego 1939.

${ }^{11}$ APM, odpis pisma z 3 kwietnia 1939.

${ }^{12}$ Odnotować można kilka drobnych odstępstw. Do okna z medalionem przedstawiającym św. Stanisława Kostkę podano jako fundatora Koło Młodzieży w Mszance, tymczasem na witrażu widnieje napis: „Koło Młodzieży Ludowej w Mszance”. Różnice w zastosowanym liternictwie sugerują, iż napis w obecnym brzmieniu jest wynikiem późniejszej rekonstrukcji. Pierwotne brzmienie podaje również: APM, Liber Memorabilium Parafii Mszanka pow. Gorlice, t. I: do 1984 [dalej: Liber memorabilium], rkps, s. 33. Okno figuralne miało przedstawiać wedle zamówienia św. Zofię, a na medalionie znaleźć się miała św. Zofia z córkami, tymczasem na oknie figuralnym mamy te cztery postaci, a na medalionie świętą ukazaną jedynie z symbolizującymi córki przedmiotami.

${ }^{13}$ Zapytanie to wyjaśnia kwestię wzmiankowanego już dopisku o gratisowym wykonaniu tych okien przez firmę, poczynionego na umowie. Ewidentnie pojawił się on tam po 3 kwietnia 1939 roku, sankcjonując w ten sposób nieznaną nam w formie pisanej odpowiedź udzieloną przez zakład w tej sprawie. 
świadczy zapis w jednym z kolejnych dokumentów ${ }^{14}$, firma w istocie otrzymała 15 kwietnia kolejną transzę ( 890 zł) zaliczki.

Określony w umowie termin realizacji witraży został dotrzymany, a już nazajutrz (26 czerwca) krakowska pracownia wystawiła rachunek opiewający na kwotę 2320 zł, z którego wynika, iż wykonała (zgodnie ze stanem obecnym): 2 witraże figuralne umieszczone po bokach ołtarza głównego w cenie $300 \mathrm{zł}$ za każdy, 8 witraży geometrycznych $\mathrm{z}$ medalionami w ścianach korpusu i na zakończeniu ramion transeptu w cenie po 215 zł za każdy oraz 2 małe witraże przy wejściu, pod chórem muzycznym, bezpłatnie. Każdy z witraży (z wyjątkiem dwóch ostatnich) miał wysokość pomiędzy 288 a $292 \mathrm{~cm}$, zaś szerokość 121 lub - w czterech przypadkach - $142 \mathrm{~cm}$. Adnotacja na rachunku informuje, iż brakującą kwotę $1160 \mathrm{zł}$ uiszczono 1 lipca ${ }^{15}$, finalizując transakcję.

Sprawa witraży w Mszance na tym się jednak nie kończy. Jak odnotowano w kronice parafialnej: „szkło na okna jest grube i kolorowe. [...] Poszczególne szybki zostały osadzone sposobem witrażowym w szynach ołowianych, niestety słabo, wcale nie kitowane, i dlatego od pierwszej chwili wiatr poruszał całymi oknami, osłabiając obsadzone szkło w tych szynach. Same witraże pięknie wykonane, obsadzenie w otworach okiennych zupełnie sfuszerowane" ${ }^{\prime \prime}$. Nieco dalej czytamy tam znowu: „Robota nie była solidna. W czasie wiatru całe okna ruszały się i zdawało się, że wypadną na kościół. Od 1943 r. zaczęły wypadać pojedyncze szyby. Zatykaliśmy dziury deskami od wewnątrz i w ten sposób wzmacniali okna. W roku 1949 podjęto się naprawy okien" ${ }^{17}$.

Zapewne z powodu wojny, a po jej zakończeniu z racji zaprzestania działalności przez zakład Romańczyka, zadanie to musiano odsunąć w czasie i powierzyć innej firmie. 31 maja 1949 roku parafia w Mszance zwróciła się do zakładu S. G. Żeleński w Krakowie o - „możliwie spieszne” (jak wyraźnie zaznaczono) - przedstawienie oferty na naprawienie witraży w kościele, podając ich kształt i wymiary ${ }^{18}$.

W odpowiedzi udzielonej 2 czerwca zakład uznał te dane za niewystarczające i wskazał na konieczność przysłania własnego pracownika, który zbadałby sprawę

\footnotetext{
${ }^{14}$ APM, rachunek z 26 czerwca 1939.

${ }^{15}$ Tamże. Rzecz zastanawiająca, iż w APM, Liber memorabilium, s. 32-33 spotykamy informację, iż „okna zostały wstawione w kościele w pierwszych dniach lipca 1939 roku”.

16 Tamże.

${ }^{17}$ Tamże, s. 69.

${ }^{18}$ APM, odpis pisma z 31 maja 1949. Korespondencja dotyczyła 10 prostokątnych okien zakończonych półkoliście (cyrklasto), z których 4 miało wymiary: 3,00x1,45 m, a 6 wymiary: 3,00x1,15 m, z czego wynika, iż z planowanych prac wyłączone były dwa okrągłe okienka znajdujące się w fasadzie kościoła, po bokach wejścia głównego. W piśmie tym zakreślono wizję remontu, sformułowaną na podstawie znajomości zniszczeń: „,[...] okna witrażowe są częściowo zniszczone i wymagają remontu, a mianowicie: rozebrania istniejących witraży i wykonania z uzyskanego materiału $\mathrm{z}$ dodaniem około $10 \%$ procent nowego materiału nowych witraży według dawnego rysunku”.
} 
na miejscu, co oznaczało poniesienie przez parafię kosztów podróży i wypłatę wynagrodzenia w wysokości 160 zł za godzinę. Firma deklarowała, iż mogłoby do takiej wizyty dojść już w kolejnym tygodniu i że nie zajęłaby ona więcej jak jeden dzień, przy czym konieczne byłoby do dokonania oględzin użyczenie drabiny. Odpisujący w imieniu firmy Adam Żeleński nie był zaskoczony charakterem zlecenia, w swej odpowiedzi przywołał nawet kilka przykładów wykonywanych ostatnio przez firmę prac, zarówno naprawczych, jak i autorskich, tak w okolicach Mszanki, jak i daleko od Krakowa ${ }^{19}$.

14 czerwca parafia sformułowała odpowiedź, a 4 dni później Adam Żeleński zgłosił gotowość przysłania do Mszanki swego pracownika, Mieczysława Widło, celem dokonania oględzin witraży i opracowania wstępnego kosztorysu, przy którego akceptacji przez parafię można by - w razie takiej potrzeby - od razu pobrać próbki szkieł oraz złożyć zlecenie i przekazać za pośrednictwem przedstawiciela zakładu zaliczkę na prace ${ }^{20}$.

Kolejny list Żeleńskiego, z 22 czerwca, informuje, iż Widło odwiedził już Mszankę i na podstawie jego oględzin sporządzony został kosztorys, opiewający na kwotę 120000 zł (wraz z materiałami), w którym nakreślono zakres prac, deklarując przeprowadzenie ich już w lipcu. Oczekiwano przy tym na decyzję parafii co do ostatecznego zakresu i zaliczkę w wysokości połowy wartości robót określonej w kosztorysie. Aby uwiarygodnić firmę, Adam Żeleński dodał na końcu listu cenny dla nas spis prac wykonanych przez zakład w pierwszej połowie 1949 roku $^{21}$.

${ }^{19}$ APM, pismo z 2 czerwca 1949. Żeleński wymienił tu prace naprawcze w Bieczu, Jedliczu, Korczynie, Krościenku i Polance Karol, a także nowe realizacje w Świdnicy na Śląsku oraz - bez podania nazw miejscowości - na terenie diecezji lubelskiej i siedleckiej. Wspomniane prace naprawcze dotyczyły najpewniej witraży, które zakład ten, o czym wiemy, zrealizował w poprzednich latach swojej działalności, a to: w kościołach parafialnych (Jedlicze, Korczyna, Krościenko Wyżne, Polanka Karol) i kościele reformatów (Biecz). Część z tych realizacji znalazła rozwinięcie w piśmie z 22 czerwca 1949.

${ }^{20}$ APM, pismo z 18 czerwca 1949.

${ }^{21}$ APM, pismo z 22 czerwca 1949. Prace te miały objąć: wymontowanie 10 okien (stanowiących łącznie 32 kwatery), naprawę ołowianych spoin, zakitowanie wszystkich kwater, uzupełnienie brakujących szkieł (w tym dorobienie brakującej 1/3 dolnej części witrażu ze św. Piotrem oraz ubytków w 4 kwaterach geometrycznych), dolutowanie miedzianych drucików i wprowadzenie - po ponownym zamontowaniu okien - usztywniających witraże wiatrówek (z prętów grubszych niż dotychczas i w podwójnej ilości w dolnych partiach). W tak skalkulowanym kosztorysie nie były uwzględnione koszty dodatkowe, które miała wziąć na siebie parafia, a mianowicie: przewóz materiałów, przejazd dwóch monterów w obie strony, opłacenie czasu ich podróży i pobytu (szacowanego przez Żeleńskiego na 8-10 dni) oraz utrzymania, zapewnienie rusztowań, murarzy i pomocy do czyszczenia kwater, a także dostarczenie $6 \mathrm{~kg}$ pokostu lnianego i $25 \mathrm{~kg}$ kredy. Wobec planów parafii odnośnie do zamontowania wentylatorów Żeleński radził zamówienie 4, a minimum 2 sztuk wentylatorów zatrzaskowych, montowanych w nawie i kaplicy (właściwie: ramieniu transeptu), w dolnych partiach witraży (ze względu na medaliony), kosztujące około $15700 \mathrm{zł}$. 
Pismo Żeleńskiego z 6 lipca, skierowane na ręce ks. proboszcza Józefa Głuca, dowodzi, iż parafia zdecydowała się na proponowany przez właściciela zakładu zakres robót (wraz z wykonaniem dwóch wentylatorów), prosiła jednak o udzielenie pewnych wyjaśnień. Wynika z nich m.in., iż na przeszkodzie niezwłocznego podjęcia prac w Mszance stała kwestia konieczności uprzedniego wykonania wentylatorów w zakładzie ślusarskim. Żeleński szacował, iż mogą być one gotowe za około dwa tygodnie. Co istotne, w piśmie tym potwierdził proboszczowi otrzymanie $60000 \mathrm{zl}$ tytułem zaliczki na prace 22 .

W liście z 2 sierpnia Żeleński oznajmił fakt nadania koleją (do stacji Wola Łużańska) przesyłki zawierającej 2 wentylatory, 36 wiatrówek oraz skrzynkę z materiałami i kitem. W związku z planowanym wysłaniem 8 lub 9 sierpnia monterów prosił proboszcza o poczynienie wszystkich ustalonych wcześniej przygotowań. Do listu załączył kopię listu przewozowego celem ułatwienia odbioru przesyłki ze stacji ${ }^{23}$.

Do zapowiedzianej wizyty doszło 8 sierpnia, a została ona zakończona 18 sierpnia, kiedy to proboszcz wystosował informujące o tym pismo do zakładu, przekazując zarazem resztę należności za prace (60 $000 \mathrm{zl)}$ i wentylatory (15 $700 \mathrm{zl})$. Okazało się jednak, iż przy montażu trzy fragmenty szkła z napisami pękły i należało je jeszcze wymienić. Pomimo tego puenta listu była pochlebna: „Za solidne naprawienie okien w naszym kościele składamy serdeczne podziękowanie oraz łączymy wyrazy należnej czci”"24. W odpowiedzi zakład już nazajutrz wystawił urzędowi parafialnemu w Mszance rachunek na kwotę zgodną z kosztorysem i ustaleniami co do wentylatorów i 20 sierpnia wysłał go wraz z pismem przewodnim do parafii, proponując zarazem konkretne rozwiązania dotyczące pękniętych szyb z napisami. Już wtedy były one w naprawie, Żeleński pisał: ,gdy monterzy je tu przywieźli, od razu zostały wycięte nowe szkła i zaczęte malowanie liter. Gdy nowe, naszej roboty napisy będą gotowe, to [...] monter nasz wstąpi do Mszanki i napisy te wprawi”. Spodziewał się przy tym, iż nastąpi to we wrześniu. Wedle propozycji właściciela koszt materiałów i wypalania zakład wziął na siebie, parafia miała jedynie zapłacić za malowanie, dojazd i montaż $\dot{z}^{25}$. Tak się zapewne stało, gdyż cała sprawa nie ma już dalszego ciągu potwierdzonego zapisami archiwalnymi. Kronika parafialna

${ }^{22}$ APM, pismo z 6 lipca 1949. Żeleński wyjaśniał w nim, dlaczego korzystniej jest, aby parafia płaciła bezpośrednio pracownikom („są to koszty NETTO bez ich obciążeń i bez naszego jakiegoś w tym udziału”) oraz dlaczego oczekuje dostarczenia pokostu i kredy („Zakład nie ma swojej olejarni, tylko kupuje pokosty i dziś nie ma się nigdy pewności, czy zakupiony choćby najdroższy pokost jest prawdziwy - gdy natomiast własny pokost, zebrany w Parafii - na pewno będzie doborowy, najlepszy").

${ }^{23}$ APM, pismo z 2 sierpnia 1949 i list przewozowy (kopia) z 2 sierpnia 1949 potwierdzony pieczęcią na stacji Wola Łużańska 4 sierpnia 1949. Potwierdzenie zaplanowanego przybycia monterów (Władysława Jaworskiego i Mieczysława Widło) oraz poczynionych ustaleń co do zapłaty i zakresu zaangażowania parafii w naprawę zawiera: APM, pismo z 6 sierpnia 1949.

${ }^{24}$ APM, kopia pisma z 18 sierpnia 1949.

${ }^{25}$ APM, rachunek z 19 sierpnia 1949 i pismo z 20 sierpnia 1949. 
cały proces naprawy witraży opisuje bardzo lakonicznie: „Okna te zostały zupełnie wyjęte przez murarza Stanisława Szymczyka z Mszanki i przez pracowników firmy p. Jaworskiego Władysława i p. Widło Mieczysława, na nowo wykonane w oknach od 8 sierpnia do 18 sierpnia. Koszta naprawy 10 okien wyniosły 120000 zł”26.

\section{Analiza}

\section{Zakład Maksymiliana Romańczyka i jego poprzednicy}

$\mathrm{Na}$ marginesie zamówienia do Mszanki rysuje się kilka istotnych kwestii dotyczących funkcjonowania zakładu Maksymiliana Romańczyka. $Z$ dokumentów zachowanych w Mszance wynika, iż w okresie realizacji tego zamówienia (od 24 lutego do 26 czerwca 1939 roku), a zapewne i wcześniej, pracownia ta posługiwała się w kontaktach z klientami papierem firmowym z nagłówkiem o treści: „Zakład Witrażów i Oszkleń Artystycznych Maksymilian Romańczyk (dawniej Teodor Zajdzikowski i syn)”, z adresem „KRAKÓW, ULICA ŚW. JANA L. 30”, numerem telefonu i datą założenia zakładu, określoną na rok 1864 (sic!) (il. 12).

W prowadzonej korespondencji mamy też do czynienia z konsekwentnie stosowaną zakładową pieczątką, na której każdorazowo podpisywał się ktoś w zastępstwie właściciela firmy (stale ta sama osoba, podpis nieczytelny z adnotacją „w.z.”), przypuszczalnie kierownik zakładu lub pracownik upoważniony przez Romańczyka do prowadzenia tej konkretnej sprawy. Mocno rozbudowany napis na pieczątce brzmi: „ZAKŁAD WITRAŻOWO-SZKLARSKI / ZAŁOŻONY W R. 1864. / M. ROMAŃCZYK / DAWNIEJ / T. ZAJDZIKOWSKI I SYN / Kraków, Św. Jana 30 Tel. 126-46" (il. 13). Jedyna istotna różnica w stosunku do treści nagłówka na papierze firmowym polega tu na wyraźnym zaakcentowaniu nie tylko artystycznego, ale i szklarskiego, rzemieślniczego charakteru działalności.

W kontekście tych danych rodzi się kilka ważnych pytań: dlaczego jako czas założenia firmy podawano rok 1864? Dlaczego odwoływano się do tradycji związanej tylko z Zajdzikowskim, a pominięto zupełnie poprzedniego dzierżawcę Jana Kusiaka, który pomimo stosunkowo krótkiego okresu takiej formy aktywności zbudował sobie niezłą markę? Jaką rolę w funkcjonowaniu zakładu i kiedy odgrywał

${ }^{26}$ To samo źródło informuje, iż przy okazji tej naprawy w okna wmontowano „dwa wentylatory zatrzaskowe” (koszt 15700 zł), a ponadto opłacono ,przewóz, murarza, rusztowanie i dziesięciodniową pracę dwóch pracowników wraz z utrzymaniem”. W rezultacie całkowity koszt naprawy witraży osiągnął kwotę 164300 zł (APM, Liber memorabilium, s. 70). Wentylatory, czyli ślusarsko opracowane ramy umożliwiające uchylanie części okna i wietrzenie wnętrza świątyni, zostały wkomponowane w witraże: Najświętsze Serce Pana Jezusa (w ramieniu transpetu) i Św. Zofia (w korpusie nawowym), tj. w miejscach zaleconych przez Adama Żeleńskiego. 
ów, eksponowany na papierze firmowym i pieczątce, także za czasów dzierżawy Kusiaka, syn Teodora Zajdzikowskiego?

Zakładem Zajdzikowskiego zajmowano się w badaniach nad witrażami marginalnie $^{27}$, dopóki Danuta Czapczyńska-Kleszczyńska nie zebrała dostępnego jej materiału w formie artykułu, a następnie fragmentu większego opracowania o krakowskich witrażach ${ }^{28}$. W ich świetle Zajdzikowski urodził się w roku 1840, a w roku 1863 poślubił Marię Szkolnikowską, córkę krakowskiego krawca, z którą miał liczne potomstwo: pięciu synów i cztery córki. W latach 60 . XIX wieku urodziły się im dwie córki: Maria (1864) i Franciszka (1865) ${ }^{29}$. To niestety wszystko, co wiadomo do tej pory o wczesnych latach życia tego ważnego twórcy. Twierdzenie, iż pracował jako zwykły szklarz aż do roku 1880, kiedy to na parterze kamienicy przy ul. św. Jana 17 otworzył własny zakład, zostało oparte na nadruku na papierze firmowym ${ }^{30}$. Bliższa analiza tej kwestii prowadzi do konstatacji, iż ów papier firmowy pochodzi z roku... 1929, kiedy to nie żył zarówno sam Teodor (zm. 1907), jak i związany podobno z zakładem jego syn Marian (zm. 1923), a firma pozostawała w ręku dzierżawcy, Jana Kusiaka. Tymczasem okazuje się, iż papiery firmowe zakładu Zajdzikowskiego z okresu, kiedy osobiście kierował on firmą, nie zawierają danych o dacie jej założenia, co dowodzi, iż dopiero jego następcy zaczęli używać tego typu informacji, zapewne po to, aby wyeksponować wieloletnie doświadczenie firmy, podkreślić ciągłość działalności pomimo zmiany prowadzącego zakład, a także dlatego, iż taki był obyczaj wśród tego typu pracowni. Dla samego Zajdzikowskiego nie miało to większego znaczenia, wszak względem klientów sam był ,żywym świadectwem" ciągłości swej pracy, przejście od działalności jednoosobowej do liczącego więcej osób warsztatu, co można by przyjąć jako wyznacznik do używania nazwy „zakład” (równie dobrze mogło to być jednak określone konkretnymi przepisami obowiązującymi wówczas rzemieślników czy przemysłowców), było dlań naturalnym procesem związanym z rozwojem zawodowym, a w swoim fachu czuł się aktywny „od zawsze”, tj. od chwili podjęcia aktywności zawodowej. Wiemy, że sam Zajdzikowski oficjalnie określał się mianem „szklarza” jeszcze w roku 1899,

${ }^{27}$ Zob. np. M. Reinhard-Chlanda, Witraże kościołów Kleparza. Z prac nad katalogiem zabytków, [w:] Dziedzictwo polskiej sztuki witrażowej, red. K. Pawłowska i J. Budyn-Kamykowska, Kraków 2000, s. 127; A. Laskowski, Działalność Krakowskiego Zakładu Witrażów Władysława Ekielskiego i Antoniego Tucha, [w:] Dziedzictwo polskiej sztuki witrażowej, dz. cyt., s. 135.

${ }^{28}$ Zob. D. Czapczyńska-Kleszczyńska, Teodor Andrzej Zajdzikowski (1840-1907). Pionier krakowskich witrażowników, „Rocznik Krakowski” 69 (2003), s. 151-170. W wersji popularyzatorskiej także: D. Czapczyńska, Teodor Zajdzikowski, „Witraż” 1 (2), 2002, s. 30-32. Później także: taż, Witraże w Krakowie. Dzieła i twórcy, Kraków 2005, s. 37-41 i 62-65, Krakowska Teka Konserwatorska, t. 5.

${ }^{29}$ D. Czapczyńska-Kleszczyńska, Teodor Andrzej Zajdzikowski (1840-1907), dz. cyt., s. 151-152.

${ }^{30}$ Tamże, s. 154. Datowanie to, przyjęte za pewnik, jest powtarzane w kolejnych publikacjach. Por. D. Czapczyńska-Kleszczyńska, Zapomniani twórcy. Stan badań nad polskim witrażownictwem (druga połowa XIX - rok 1945), „Sacrum et Decorum” 1 (2008), s. 107. 
jednak około roku 1902 stosował już określenie „zakład artystyczno-szklarski” ${ }^{31}$. Do zmiany formuły (czy choćby tylko nazwy) musiało zatem dojść na przełomie XIX i XX wieku, być może w roku 1902 w obliczu powstania na gruncie krakowskim poważnej konkurencji w postaci zakładu witrażowego Władysława Ekielskiego i Antoniego Tucha.

$\mathrm{Z}$ tej perspektywy umieszczenie na papierze firmowym daty 1864 (zamiast stosowanej przez Kusiaka daty 1880) można widzieć jako świadomą próbę „postarzenia” firmy i nadania jej nobliwego charakteru ${ }^{32}$. Niekoniecznie musi to oznaczać, iż wczesne datowanie zakładu Zajdzikowskiego należy odrzucić. Mocnym argumentem za datowaniem go przynajmniej na rok 1882 jest medal państwowy przyznany mu w tymże roku za okna kościelne na wystawie w Przemyślu, czym chwalił się w nadruku rachunku wystawionego 18 grudnia 1888 roku, a stosowanego w powielanej formie co najwyżej od roku $1887^{33}$. Z kolei przekaz prasowy z roku 1880 informuje o dużym zleceniu ( 22 witraże) ukończonym przezeń tego roku w kościele parafialnym w Zarzeczu ${ }^{34}$. Kwestia ta niewątpliwie pokazuje, iż należy zawsze pozostawać krytycznym wobec odnalezionych źródeł, a sprawę założenia zakładu Zajdzikowskiego, tak istotną dla dziejów polskiego witrażownictwa ${ }^{35}$, pozostawia wciąż otwartą i wymagającą dalszych badań. Zamykając ją w tym miejscu warto wyrazić przypuszczenie, iż data 1864 miała jednak jakieś uzasadnienie w faktach i mogła się odnosić np. do rozpoczęcia przez Teodora Zajdzikowskiego działalności zawodowej w branży szklarskiej lub uzyskania przezeń uprawnień do

${ }^{31}$ Zob. D. Czapczyńska, Uwagi o działalności krakowskich firm witrażowniczych w latach 1900-1939. Na marginesie prac nad katalogiem witraży w kamienicach i budynkach użyteczności publicznej w Krakowie, „Biuletyn Historii Sztuki” 47 (1985) nr 1-2, s. 212, il. 1 (inserat z 1899 roku) oraz D. Czapczyńska-Kleszczyńska, Teodor Andrzej Zajdzikowski (1840-1907), dz. cyt., s. 154 (nadruk firmowy na rachunku, tu nieprecyzyjnie datowany na czas około 1900, podczas gdy w treści reprodukowanego nadruku informacja o wyróżnieniu otrzymanym przez zakład w 1902 roku).

${ }^{32}$ Warto wspomnieć, iż nagminne było stosowanie takiego zabiegu względem siedzib ziemiańskich, zwłaszcza tych przejętych przez przemysłowców, por. A. Laskowski, Między folwarkiem a szybem. Ziemianie galicyjscy a nafta na przykładzie Jasła i powiatu jasielskiego, „Studia z Historii Społeczno-Gospodarczej XIX i XX Wieku" 8 (2010), s. 130.

${ }^{33}$ Zob. D. Czapczyńska-Kleszczyńska, Teodor Andrzej Zajdzikowski (1840-1907), dz. cyt., s. 153, il. 3. Przemawia za tym informacja w nagłówku papieru firmowego o srebrnym medalu na wystawie krajowej w Krakowie, jaki zakład Zajdzikowskiego miał otrzymać właśnie w roku 1887. Jego udział i fakt otrzymania nagrody na pierwszej z wystaw potwierdza artykuł prasowy Wystawa Przemyska, „Dźwignia” 6 (1882) nr 10, s. 155.

${ }^{34}$ Kościół w Zarzeczu..., „Dźwignia” 4 (1880) nr 11, s. 98.

${ }^{35}$ Sprawa ta wydaje się ważniejsza dla badaczy, niż dla samego Zajdzikowskiego, o czym wspomniałem już wcześniej. Gdyby w istocie udało się udowodnić, iż jego zakład zajmował się wykonywaniem witraży od roku 1864, wówczas mielibyśmy do czynienia z firmą witrażową (witrażownikiem) najstarszą już nie tylko w Galicji, ale generalnie na ziemiach polskich. Najstarsza znana do tej pory praca Zajdzikowskiego to jego zaangażowanie przy szkleniu okien w kościele św. Floriana w Krakowie w roku 1872 (zob. D. Czapczyńska-Kleszczyńska, Teodor Andrzej Zajdzikowski (1840-1907), dz. cyt., s. 157). 
prowadzenia samodzielnej działalności w tym zakresie. Wiek 24 lata, jaki wówczas osiągnął, oraz fakt założenia rodziny (ożenek i narodziny pierwszego dziecka) zdają się przemawiać za tą tezą.

Podobnie wygląda sprawa $\mathrm{z}$ funkcjonowaniem pracowni Zajdzikowskiego po śmierci jej założyciela, która nastąpiła 28 sierpnia 1907 roku po długiej chorobie, a zatem nie była to śmierć nagła i niespodziewana, co - jak się wydaje - pozwalało właścicielowi osobiście podjąć decyzję o dalszych losach zakładu. Co jednak intrygujące, o działalności zakładu w ciągu kolejnych kilkunastu lat po śmierci Teodora nic nie wiemy. Syn Marian (1879-1923), który - jak się przyjmuje - przejął po nim firmę, zmarł (podobnie jak ojciec: po długiej i ciężkiej chorobie) 15 czerwca $1923 \mathrm{roku}^{36}$. Z tego okresu (1907-1923) nie są wymieniane w literaturze żadne realizacje witrażowe firmy Zajdzikowskiego, co skłania do przypuszczenia, iż albo przestała ona w tym czasie wykonywać witraże i zajmowała się wyłącznie rzemiosłem szklarskim albo też w zupełności zawiesiła działalność ${ }^{37}$.

Nowy rozdział w jej dziejach został otwarty dopiero w momencie wydzierżawienia jej Janowi Kusiakowi, co nastąpiło zapewne w drugiej połowie 1925 roku $^{38}$. Okoliczności przejścia zakładu (jego dzierżawy?) z rąk Kusiaka do rąk Maksymiliana Romańczyka nie są dokładnie wyjaśnione. Zgłębiająca ten problem Danuta Czapczyńska-Kleszczyńska ustaliła, iż bracia Fryderyk i Maksymilian Romańczyk byli zatrudnieni w firmie S. G. Żeleński, a po nieudanej próbie zakupu zapasu szkła i urządzeń upadającej firmy „Industria” (w czym ubiegła ich Iza Żeleńska) rozstali się z dotychczasowym pracodawcą i związali z pracownią Jana Kusiaka. Związek z nią Fryderyka trwał krótko i zakończył się założeniem w roku 1931 własnego zakładu, natomiast Maksymilian prawdopodobnie przejął pracownię od Kusiaka w pierwszej połowie lat 30. XX wieku, najpewniej do 1934 roku. Funkcjonująca pod jego auspicjami jeszcze w okresie okupacji pracownia została zamknięta w 1945 roku, już po zakończeniu II wojny światowej, a jej likwidatorem był Kazimierz Zajdzikowski (1877-1951), syn Teodora i brat Mariana. Podaje się również, że

${ }^{36}$ Tamże, s. 151-152 i 156.

${ }^{37}$ Jak się wydaje, w okresie przejściowym (1923-1925) firma funkcjonowała, bowiem w roku 1924 zamieściła ogłoszenie w czasopiśmie „Przemysł, Rzemiosło, Sztuka” 4 (1924) bns (wklejka reklamowa przed s. III okładki), oferując swe usługi jako „TEODOR ZAJDZIKOWSKI I SYN / ZAKŁAD ARTYSTYCZNO-SZKLARSKI MALOWANIA OKIEN KOŚCIELNYCH”, który m.in. „PODEJMUJE SIĘ ROBÓT SZKLARSKICH - OSZKLENIA POJEDYNCZYCH OKIEN I WIĘKSZYCH BUDOWLI [...]”. Pytanie, kto nią wówczas kierował, pozostaje otwarte.

${ }^{38}$ Data rozpoczęcia samej dzierżawy ani jej warunki nie są znane. Prowadzenie pracowni szklarsko-witrażowej (przypuszczalnie tożsamej już z dawną pracownią Zajdzikowskiego) Kusiak zgłosił 24 lipca, kartę przemysłową otrzymał 13 października, a już 1 września złożył ofertę z własnym podpisem na pieczątce Zajdzikowskiego i papierze firmowym z nagłówkiem: „ZAKŁAD WITRAŻOWOSZKLARSKI / POD FIRMĄ/TEODOR ZAJDZIKOWSKI I SYN” (por. D. Czapczyńska-Kleszczyńska, Witraże w Krakowie, dz. cyt., s. 62-63). 
po śmierci brata Fryderyka w roku 1949 Maksymilian Romańczyk przeją jego pracownię działającą w Siemianowicach Śląskich ${ }^{39}$.

Badania prowadzone przeze mnie od kilku lat na obszarze dzisiejszej diecezji tarnowskiej pozwalają na wprowadzenie kilku uzupełnień do tych ustaleń. Pierwsze dotyczy samych początków działalności zakładu Kusiaka. Już w roku 1925, a zatem u zarania swej działalności, zakład ten wykonał parę znakomitych witraży projektu Zdzisława Gedliczki (Pokłon pasterzy i Pokłon Trzech Króli) do prezbiterium kościoła parafialnego pw. NMP Wniebowziętej w Wietrzychowicach (il. 14) ${ }^{40}$. $\mathrm{Na}$ drugim biegunie mamy datowaną realizację z 1931 roku - zespół witraży w zamknięciu prezbiterium kościoła Misjonarzy w Tarnowie, a raczej - jak się wydaje - przeprowadzenie napraw ich partii ornamentalnych oraz wypełnienie na nowo wieńczących je rozet. Rzecz zadziwiająca, iż w okresie tym mamy do czynienia zarówno z sygnaturami samego Kusiaka (jak w przywołanych właśnie przykładach), jak i z sygnaturami zakładu Zajdzikowskiego, na przykład w kościele parafialnym pw. św. Józefa Oblubieńca NMP w Bystrej, na witrażach z 1926 roku, gdzie u dołu jednego z nich zachował się (częściowo zamurowany) napis: „WYKONAŁA FIRMA / [...] ZAJDZIKOWSKI" (il. 15). Sytuacja ta mogłaby rodzić przypuszczenie, iż chodzi o dwa zupełnie różne, niezależne od siebie zakłady. We wszystkich tych przypadkach mamy jednak do czynienia z tym samym adresem zakładu (Kraków, ul. św. Jana 30), a ewentualne dalsze wątpliwości zdaje się rozwiewać sytuacja, z jaką mamy do czynienia w Szczepanowie, gdzie na zespole witraży projektu Józefa Dutkiewicza, pochodzących z okresu dzierżawy Kusiaka, spotykamy sygnatury... zarówno Kusiaka (na konsoli pod postacią św. Benedykta), jak i Zajdzikowskiego (na konsoli pod wizerunkiem Matki Boskiej) jako wykonawców, przy czym witraże te nie różnią się (stylistycznie, warsztatowo) między sobą absolutnie niczym poza samym tematem przedstawieńn ${ }^{41}$.

Jeśli chodzi o wczesne prace Maksymiliana Romańczyka, to na podstawie badań terenowych przywołać mogę zespół witraży o tematyce eucharystycznej w prezbiterium kościoła św. Mikołaja w Rychwałdzie z 1935 roku, z których jeden posiada sygnaturę tego twórcy, z podkreśleniem jego krakowskiego rodowodu (il. 16).

${ }^{39}$ Tamże, s. 63-65. Wydarzeniem zbieżnym z likwidacją zakładu w 1945 roku może być fakt ofiarowania przez Kazimierza Zajdzikowskiego Muzeum Narodowemu w Krakowie czterech tek z dokumentacją witraży mariackich, za co podziękowanie wystosował do niego w październiku ówczesny dyrektor placówki Feliks Kopera (D. Czapczyńska-Kleszczyńska, Teodor Andrzej Zajdzikowski (1840-1907), dz. cyt., s. 168-169). Wedle wyjaśnień udzielonych mi przez Irenę Kontny na podstawie relacji rodziny Fryderyka Romańczyka (za które uprzejmie dziękuję) zakład po śmierci Fryderyka prowadziła jego żona (do roku 1974), a w latach 50. XX w. pracował w nim Maksymilian i syn Fryderyka, Jan. W świetle tych samych relacji przed wojną bracia nie współpracowali ze sobą.

${ }^{40} \mathrm{Na}$ obu witrażach znajdują się sygnatury zakładu i projektanta, na jednym z nich roczna data wykonania.

${ }^{41} \mathrm{O}$ witrażach tych zob. A. Laskowski, Witraże jako przedmiot zainteresowania krakowskiego urzędu konserwatorskiego w okresie międzywojennym, „Teki Krakowskie” t. 16, 2009, s. 111-113. 
Utrzymane $\mathrm{w}$ jaskrawej kolorystyce, $\mathrm{z}$ bogatą, a wręcz przesadną ornamentyką witraże rychwałdzkie (il. 17) odbiegają znacznie od stylu stonowanych witraży w Mszance, choć i tu przedstawienia figuralne ujęte zostały w okrągłych medalionach.

Pierwszy materialny ślad działalności Maksymiliana Romańczyka na terenie diecezji tarnowskiej (w jej obecnych granicach), do której administracyjnie należy parafia w Mszance, to zespół witraży w kościele parafialnym Św. Zygmunta w Żelichowie, pochodzący z 1938 roku (zamontowano je dokładnie 24 październi$\mathrm{ka})^{42}$, tj. powstały rok przed witrażami w Mszance. Okna te, ujęte cienką bordiurą, operują medalionami z przedstawieniami świętych w popiersiu lub symbolami umieszczonymi na tle rozchodzących się od nich promieni lub geometrycznego wzoru (il. 18) ${ }^{43}$. Swoją prostotą i oszczędnością zastosowanych środków wyrazu korespondują z późniejszymi pracami w Mszance. Wiadomo jednak, że już wcześniej Maksymilian Romańczyk wykonywał bliżej nieokreślone prace w kościele parafialnym w Grybowie, wystawiając za nie rachunek 23 czerwca 1937 roku $^{44}$. Natomiast w tym samym co w Mszance roku powstały dwa bardzo efektowne witraże figuralne (ze św. Hubertem i św. Izydorem), znajdujące się po obu stronach ołtarza głównego w kościele parafialnym pw. Wniebowzięcia NMP w Ostrowach Tuszowskich (il. 19); wiadomo, iż kosztowały w sumie $1000 \mathrm{zf}^{45}$. Ta ostatnia informacja jest dla nas istotna, gdyż pokazuje, iż cena witraża figuralnego o zbliżonych rozmiarach mogła się dość znacząco wahać, zapewne w zależności od klasy zatrudnionego projektanta, ale i od zasobności fundatora. Jak się wydaje, tym należy tłumaczyć fakt, iż pojedynczy witraż figuralny w Mszance był aż o 200 zł tańszy od podobnego w Ostrowach Tuszowskich.

${ }^{42}$ Archiwum Parafialne w Żelichowie, Kronika parafii Żelichów, mps, s. 14.

${ }^{43}$ Zespół ten został w ostatnich latach uzupełniony kilkoma nowymi witrażami, które nawiązują do niego zarówno kompozycją, jak i zastosowanymi materiałami.

${ }^{44}$ Zob. J. Skrabski, Kościoły Grybowa. Monografia historyczno-artystyczna, Kraków 2010, s. 147, przyp. 246.

${ }^{45}$ Witraże te są do siebie zbliżone stylistycznie i technicznie. Witraż po lewej, ze św. Izydorem, posiada sygnaturę zakładu wraz z jego adresem (Kraków, ul. Św. Jana 30) oraz nazwiska fundatorek (ANT. FOCOWA / MARIA KĘDZIOR). Witraż po prawej, ze św. Hubertem, posiada z kolei herb (Sulima) i nazwisko fundatora (JAN WŁODEK). O roku ich ufundowania i kosztach wykonania zob. S. Zych, Parafia i sanktuarium w Ostrowach Tuszowskich. Zarys dziejów, Mielec 2007, s. 21 i 51. Wobec tych informacji, opartych na przekazach archiwalnych i wiadomościach pozyskanych od rodziny Włodków, zdementować należy podaną przeze mnie niegdyś informację, iż witraże te powstały przed rokiem 1914 (por. A. Laskowski, The Stained Glass Revival in Galicia in the Second Half of the Nineteenth Century, „The Journal of Stained Glass”, vol. XXV, 2001, s. 20, fig. 9), co było i tak korektą datowania zawartego w Katalogu zabytków sztuki w Polsce, Seria Nowa, t. 3: Województwo rzeszowskie, z. 3: Kolbuszowa, Mielec i okolice, opr. i red. E. Śnieżyńska-Stolot, F. Stolot, Warszawa 1991, s. 30, gdzie podano, iż kościół pochodzi z lat 1900-1902, a witraże są współczesne kościołowi). W karcie ewidencyjnej z 1998 roku przechowywanej w Narodowym Instytucie Dziedzictwa w Warszawie witraże te datowane są wręcz na rok 1902. 
Wiemy, iż w roku 1940 Maksymilian Romańczyk wykonał część witraży autorstwa Erwina Czerwenki do górnych okien korpusu nawowego w kościele parafialnym w Wietrzychowicach, o czym świadczą zachowane na jednym z nich sygnatury projektanta i wykonawcy (il. 20) ${ }^{46}$. Ustalenie to jednoznacznie rozstrzyga dotychczasowe wątpliwości dotyczące aktywności zakładu Romańczyka w okresie okupacji: wiemy już, że zakład funkcjonował przynajmniej do roku $1940^{47}$.

Kolejnym istotnym przyczynkiem do dziejów zakładu Romańczyka jest wydrukowana w kolumnie po lewej stronie papieru firmowego oferta (il. 12). Wynika z niej, iż zakład ten wykonywał nie tylko witraże („do świątyń i budowli świeckich we wszystkich stylach wedle projektów własnych lub nadesłanych"), barwne przeszklenia (,wszelkiego rodzaju wszystkimi gatunkami szkła łączonego ołowiem”) i kompozycje ze szkła szlifowanego (,,belgijskiego lub krajowego łączonego mosiądzem”), ale także - co najbardziej zaskakujące - mozaiki (,weneckie jak i szklanne”). Podejmował się również: prac konserwatorskich w zakresie witrażownictwa (w tym względzie cenna informacja: ,na podstawie praktyki zagranicznej przeprowadza remonty witraży antycznych od XIII do XX wieku"), trawienia i matowienia szkła (tak scen figuralnych, jak i ornamentów) oraz wszelkiego rodzaju malowania na szkle (,z utrwaleniem farb przez wypalanie w specjalnym piecu”). Wykonywał wreszcie ,latarnie reklamowe, tarcze zegarowe prześwietlające i wszelkie roboty wchodzące w zakres szklarstwa", z czego wynika, iż nie ograniczał się jedynie do prac o charakterze artystycznym. Jak zapewniano, niestety bez podania konkretów, firma posiada „referencje najlepsze”, a „szkice i kartony zostają wykonane przez najwybitniejszych artystów malarzy". Dużo w tych zapewnieniach na pewno budowania pozytywnego wizerunku firmy i wzorowania się na działaniach konkurencji (przede wszystkim zakładu S. G. Żeleński), ale przynajmniej znaczna część tych deklaracji musiała znajdować pokrycie w rzeczywistości. Dwa elementy zasługują na szczególne podkreślenie: fakt wykonywania mozaik i odbyta za granicą praktyka w zakresie konserwacji witraży. Zainteresowanie badaczy techniką mozaikową

${ }^{46}$ Witraże w tej części kościoła, wykonane w roku 1940 według projektu Czerwenki, są sygnowane przez dwie pracownie: S. G. Żeleński (sygnatura na kwaterze ze sceną Wniebowstapienia, tj. po lewej stronie kościoła) i M. Romańczyka (sygnatura na partii geometrycznej poniżej kwatery ze sceną Zwiastowania, tj. po prawej stronie kościoła), co może sugerować albo przejęcie w pewnym momencie zlecenia przez jedną firmę od drugiej albo podzielenie zakresu prac na części figuralne (S. G. Żeleński) i ornamentalne (M. Romańczyk). Kwestię tę rozstrzygnąć powinna w przyszłości kwerenda archiwalna na miejscu. O twórczości witrażowej Czerwenki (bez informacji o jego pracach w Wietrzychowicach) pisał przed kilkunastu laty J. Sz. Wroński, Krakowski malarz Erwin Czerwenka i jego witraże, „Analecta Cracoviensia” 28 (1996), s. 581-593.

${ }^{47}$ Wypada nadmienić, iż niedawno opublikowana została fotografia witraża z wizerunkiem św. Rocha znajdującego się w kościele parafialnym w Iwanowicach, który powstać miał w roku 1943 za sprawą Romana Ryniewicza i Maksymiliana Romańczyka (por. D. Czapczyńska-Kleszczyńska, Zapomniani twórcy, dz. cyt., s. 120, il. 18). Jeśli w informacji tej nie ma pomyłki, to jeszcze bardziej komplikuje ona trudne do rozwikłania koleje działalności drugiego z wymienionych twórców. 
jest w Polsce wciąż mocno ograniczone; Małgorzata Reinhard-Chlanda, badająca najbogatszy zespół dzieł wykonanych w tej technice w Krakowie 1. połowy XX wieku, wynotowała trudniące się tą techniką lokalne pracownie (i ich główne dzieła), jednakże nie ma wśród nich zakładu Romańczyka ${ }^{48}$. Znalezisko w Mszance otwiera zatem zupełnie nowe pole badawcze. $Z$ kolei fakt odbycia zagranicznej praktyki przywodzi na myśl podany przez Magdę Ławicką fakt, iż w renomowanym wrocławskim Instytucie Seilera praktykował w latach 1910-1913 Fryderyk Romańczyk (a później, w okresie międzywojennym, także poznański witrażownik Stanisław Powalisz), brat Maksymiliana, określony jako witrażownik i malarz postaci ${ }^{49}$. Skłania to do przypuszczenia, iż Maksymilian mógł pójść w ślady brata, względnie powierzać mu zlecone swemu zakładowi (trudniejsze) prace konserwatorskie.

Porównując ofertę złożoną przez zakład z zawartą przezeń umową na wykonanie witraży do Mszanki, spostrzec można, iż firma skłonna była do cenowych negocjacji, chociaż nie były one znaczne. O ile za każdy z dwóch witraży figuralnych zapłacono ostatecznie o 50 zł mniej, o tyle koszt medalionów z popiersiami do witraży geometrycznych zmalał jedynie o 5 zł za każdy medalion (przy zamówieniu 8 sztuk). Na uwagę zasługuje jednak złożona i zrealizowana deklaracja o bezpłatnym wykonaniu dwóch niewielkich witraży flankujących główne wejście do kościoła.

\section{Powojenna działalność zakładu S. G. Żeleński}

Nie mniej ciekawe od opisanych wyżej są informacje na temat powojennej działalności zakładu S. G. Żeleński. Ten okres w dziejach zakładu pozostaje słabo rozpoznany; jak dotąd spotkał się on głównie z zainteresowaniem zmierzającej ku napisaniu monografii zakładu Danuty Czapczyńskiej-Kleszczyńskiej ${ }^{50}$ oraz badającego dzieje rodziny Żeleńskich Zbigniewa Sroczyńskiego ${ }^{51}$. Z ich opracowań wiemy, iż po opuszczeniu Krakowa przez Niemców 67-letnia Iza Żeleńska (1878-1956), od śmierci męża Stanisława Gabriela (1873-1914) prowadząca zakład, już w lutym 1945 roku uruchomiła go ponownie. Jej syn Adam (1905-1963) - zaangażowany w działalność zakładu od 1929 roku - dołączył do niej dopiero we wrześniu, po powrocie z obozu koncentracyjnego. Trudności w codziennej pracy nie brakowało.

${ }^{48}$ Zob. M. Reinhard-Chlanda, Mozaiki w jezuickiej bazylice Serca Jezusa, „Rocznik Krakowski” 70 (2004), s. 89-109.

${ }^{49}$ M. Ławicka, Zapomniana pracownia. Wrocławski Instytut Witrażowy Adolpha Seilera (18461945), Wrocław 2002, s. 62.

${ }^{50}$ Zob. D. Czapczyńska-Kleszczyńska, Witraże w Krakowie, dz. cyt., s. 51-58 (zwłaszcza s. 57-58); taż, Dzielna niewiasta. Iza z Madeyskich Żeleńska (1878-1956), [w:] , Żeby wiedzieć”. Studia dedykowane Helenie Małkiewiczównie, Kraków 2008, s. 337-351.

${ }^{51}$ Zob. Z. Sroczyński, Żeleńscy. Rodowód. Dzieje rodu Żeleńskich z Żelanki, Warszawa 1997, passim. Warto też zwrócić uwagę na artykuł: S. Moliński, W 100-lecie istnienia Zakładu Witrażów S. G. Żeleński, „Witraż” 2-3 (3-4), 2002, s. 70-73. 
Pomimo to zakład przeprowadzał różnorakie naprawy i konserwacje oraz realizował nowe witraże, a w roku 1947 urządził nawet jubileusz swego 45-lecia. Dużą trudność w działalności zakładu stanowił brak odpowiedniego szkła, co doprowadzało nawet do rezygnowania z potencjalnych zleceń i rekomendowania konkurencji (jak w 1950 roku przy zamawianiu witraży do kościoła w Lutomiersku koło Łaska). 31 grudnia 1952 roku zakład S. G. Żeleński został odebrany Żeleńskim i objęty przymusowym zarządem państwa. W ten sposób zakończył się najważniejszy rozdział w dziejach tego zasłużonego zakładu.

Literatura naukowa dostarcza zaskakująco skąpych danych na temat prac wykonanych w firmie S. G. Żeleński w latach bezpośrednio po II wojnie światowej. W powszechnie dostępnych opracowaniach wymienia się (w odniesieniu do lat 1945-1952) głównie prace krakowskie: naprawę witraża Stanisława Wyspiańskiego z wyobrażeniem żywiołu ognia w kościele Franciszkanów (1945), witraż fundacji proboszcza ks. Ferdynanda Machaya do kościoła Mariackiego (1945?), witraże Władysława Jastrzębskiego i Tadeusza Wojciechowskiego do kościoła Cystersów w Mogile (1946-1947) oraz konserwację zabytkowych witraży mariackich i dominikańskich (1949) ${ }^{52}$. Z prac spoza Krakowa wskazać można: montaż części (wykonanych wcześniej) okien projektu Adama Bunscha w nawach bocznych kościoła Mariackiego w Katowicach (1946), naprawę witraży w kościele parafialnym w Majdanie Królewskim (1947), witraże w kościele pw. Wniebowzięcia NMP (1950) w Haczowie, zespół witraży projektu Tadeusza Wojciechowskiego w prezbiterium katedry we Wrocławiu (1950-1952) oraz zespół 12 witraży projektu Zofii Leśniakówny w kościele parafialnym w Cieszanowie $(1952)^{53}$. Wiadomo ponadto, że w pięcioleciu 1947-1952 wykonywano w zakładzie projekty wielu twórców ${ }^{54}$.

${ }^{52}$ Zob. D. Czapczyńska, Krakowski Zakład Witrażów, Oszkleń Artystycznych i Mozaiki Szklanej S. G. Żeleński. Uwagi na marginesie prac nad monografia, [w:] Dziedzictwo polskiej sztuki witrażowej, dz. cyt., s. 158-159; taż, Dzieje witraży Stanisława Wyspiańskiego w kościele OO. Franciszkanów w Krakowie, „Rocznik Krakowski” 70 (2004), s. 87; Z. Sroczyński, Żeleńscy, dz. cyt., s. 134-135.

${ }^{53}$ Zob. „Rocznik Archidiecezji Przemyskiej” 1997, s. 202; I. Kontna, Ikonografia górnoślaskich i zagłębiowskich witraży sakralnych w II. ćwierci XX wieku (na wybranych przykładach), [w:] Sztuka witrażowa w Polsce, red. J. Budyn-Kamykowska i K. Pawłowska, Kraków 2002, s. 162-163; A. Laskowski, Z prac Regionalnego Ośrodka Badań i Dokumentacji Zabytków w Rzeszowie nad rozpoznaniem zasobu witraży na terenie Polski południowo-wschodniej, „Kwartalnik Historii Kultury Materialnej” 56 (2008), nr 1, s. 138; B. Fekecz-Tomaszewska, Kilka uwag o witrażach wspótczesnych w zabytkowych wnętrzach sakralnych Wroctawia, [w:] Witraże w obiektach zabytkowych. Między konserwacją a sztuką wspótczesna, red. J. Budyn-Kamkowska, Kraków-Malbork 2009, s. 223; M. Nikiel, Sacrum w kwiatach, [w:] Witraże secesyjne. Tendencje i motywy, red. T. Szybisty, Kraków-Legnica 2001, s. 124.

${ }^{54}$ Wymienia ich Zbigniew Sroczyński, por. tenże, Żeleńscy, dz. cyt., s. 135, podając następujące nazwiska: Borowska, Budziło, Bunsch, Cieślińska, Gawlik, Redliczka (właść. Gedliczka), Gerżabek, Giebułtowski, Jastrzębski, X. Kilian, Krygłowski, Leśniakówna, Pękalska, Śliwiński, Wojciechowski. Autor ten pisze również, iż w okresie tym powstawały witraże dla świątyń i gmachów publicznych, dziesiątki prac dla krakowskich domów, miniatury dekoracyjne oraz lampy z witrażowymi abażurami (tamże, s. 136). 
Abstrahując w tym miejscu od znanych źródeł do tego okresu działalności zakładu - znajdujących się w samym zakładzie, Muzeum Narodowym w Krakowie czy w Bibliotece Jagiellońskiej, możliwych do swobodnego wykorzystania w przyszłości - informacje zawarte w korespondencji zachowanej w Mszance zdają się być cennym uzupełnieniem wiedzy o firmie. Szczególnie dotyczy to pisma z 22 czerwca 1949 roku, w którym Adam Żeleński zamieścił spis realizacji swego zakładu datowanych na pierwszą połowę 1949 roku (właściwie: wykonanych do 22 czerwca), przeznaczonych wyłącznie do kościołó $\mathrm{w}^{55}$. $Z$ zestawienia tego wyłania się obraz bardzo pracowitego półrocza. Dzięki temu wiarygodnemu źródłu możemy bardzo precyzyjnie datować wiele nieznanych bliżej i - w niektórych przypadkach - niełączonych dotąd z zakładem S. G. Żeleński realizacji. Są to prace w następujących miejscowościach (w kolejności wymienionej w piśmie, lokalizacja według aktualnej przynależności administracyjnej): Kamionna (pow. węgrowski, woj. mazowieckie) - witraż ze św. Antonim (wykonany w miejsce zniszczonego wojną) ${ }^{56}$, Zdziarzec (pow. mielecki, woj. podkarpackie) - witraże z Sercem Pana Jezusa i św. Teresą od Dzieciątka Jezus (il. 21) ${ }^{57}$, Świdnica (woj. dolnośląskie) - rekonstrukcja zniszczonego w czasie wojny witraża z Madonną ${ }^{58}$, Lipnik (w granicach Bielska-Białej, woj. śląskie) - witraże Adama Bunscha: Wygnanie z raju i Boże Narodzenie oraz będące jeszcze wówczas w realizacji Paś owieczki moje i Przemienienie ${ }^{59}$, Jedlicze (pow. krośnieński, woj. podkarpackie) - odtworzenie zniszczonego witraża ze św. Antonim ${ }^{60}$, Straszęcin (pow. dębicki, woj. podkarpackie) - witraże: Dobry Pasterz, Matka Boska Nieustającej Pomocy i św. Józef (il. 22) ${ }^{61}$, Pacanów (pow. buski, woj. świętokrzyskie) - witraż

${ }^{55}$ APM, pismo z 22 czerwca 1949.

${ }^{56}$ Chodzi zapewne o witraż w kościele parafialnym pw. Niepokalanego Poczęcia NMP.

${ }^{57}$ Chodzi o dwa witraże usytuowane w prezbiterium kościoła parafialnego pw. Nawiedzenia NMP, wykonane w roku 1926, zniszczone w 1944 i odtworzone w 1949 roku przez firmę S. G. Żeleński.

${ }^{58}$ Witraż ten znajduje się w kościele parafialnym pw. św. Stanisława i Wacława. Podana przez Żeleńskiego informacja znajduje potwierdzenie zarówno w istniejącym napisie na witrażu, jak i w literaturze: E. Gajewska-Prorok, S. Oleszczuk, Witraże na Ślasku. XIX i pierwsza połowa XX wieku, Leipzig 2001, s. 32, il. 4 i s. 145; Ławicka, Zapomniana pracownia, dz. cyt., s. 135.

${ }^{59}$ Chodzi o witraże w kościele parafialnym pw. Narodzenia NMP i św. Walentego, dla którego Bunsch wykonał projekty witraży w latach 1948-1949 (9 okien i 3 rozety) i 1957 (1 witraż). W katalogu prac tego twórcy projekt Boże Narodzenie widnieje jako Stajenka Betlejemska, a Paś owieczki moje jako Klucze królestwa - por. Adam Bunsch 1896-1969, katalog oprac. T. Dudek-Bujarek, tekst T. Dudek-Bujarek, B. Szczypka-Gwiazda, H. Pyka, Bielsko-Biała 1992, s. 201.

${ }^{60} \mathrm{~W}$ tutejszym kościele parafialnym pw. św. Antoniego Padewskiego wykonano w okresie międzywojennym witraże według projektu Jana Wałacha (por. M. Gładysz, O wystawie polskiej sztuki religijnej w Katowicach, [w:] O polskiej sztuce religijnej, red. J. Langman, Katowice 1932, s. 208 i 212). Zostały one poważnie uszkodzone w czasie ostrzału artyleryjskiego prowadzonego przez wojska radzieckie podczas ofensywy w dniu 8 września 1944 roku.

${ }^{61}$ Witraże te znajdują się w zamknięciu prezbiterium kościoła parafialnego pw. Wszystkich Świętych i Niepokalanego Serca NMP. Znajdujące się na nich inskrypcje potwierdzają wykonanie ich w roku 
geometryczny (w miejsce zniszczonego w czasie wojny) ${ }^{62}$, Miejsce Piastowe (pow. krośnieński, woj. podkarpackie) - 12 witraży czekających na zamontowanie ${ }^{63}$, Krępa [Górna lub Kościelna] (pow. lipski, woj. mazowieckie) - witraż Serce Marii zaprojektowany przez Zofię Leśniakównę ${ }^{64}$, Bachowice (pow. wadowicki, woj. małopolskie) - 3 witraże geometryczne ${ }^{65}$, Wadowice (woj. małopolskie) - witraże u OO. Karmelitów: 1 nowy i naprawa 5 zniszczonych podczas wojny ${ }^{66}$, Łopiennik [Górny] (pow. krasnostawski, woj. lubelskie) - 1 nowy witraż i naprawa 3 zniszczonych podczas wojny ${ }^{67}$, oraz Kraków (woj. małopolskie) - konserwacja i rekonstrukcja średniowiecznych witraży dominikańskich ${ }^{68}$.

Materiały przechowywane w archiwum parafialnym w Mszance informują o jeszcze kilku powojennych realizacjach zakładu S. G. Żeleński. W piśmie z 2 sierpnia 1949 roku Adam Żeleński podał informację o powrocie monterów „Z roboty w M. Piastowym” oraz o ich wyjeździe do Zduńskiej Woli i Łodzi ${ }^{69}$.

Ponadto w omawianym już piśmie Adama Żeleńskiego z 22 sierpnia 1949 roku pojawia się propozycja dokonania ostatecznych napraw pękniętych szkieł w kościele w Mszance ,przy sposobności roboty w Żmigrodzie”. Niewątpliwie chodziło w tym przypadku o zakrojone na szeroką skalę prace naprawcze przy witrażach w kościele parafialnym pw. Świętych Apostołów Piotra i Pawła w Nowym Żmigrodzie, wykonanych dawniej w zakładzie S. G. Żeleński i poważnie uszkodzonych w czasie II wojny światowej (il. 23) ${ }^{70}$.

1949 przez zakład S. G. Żeleński. Marian Kornecki datuje je na lata 1949-1950, por. tenże, Kościoły diecezji tarnowskiej, dz. cyt., s. 186.

${ }^{62}$ Chodzi zapewne o miejscowy kościół parafialny pw. św. Marcina.

${ }^{63}$ Chodziło zapewne o naprawę witraży z 1908 roku w tamtejszym kościele parafialnym pw. Nawiedzenia NMP, uszkodzonych w czasie wojny, o których wzmianka na tablicy przed kościołem. Druga ze świątyń w tej miejscowości, sanktuarium św. Michała Archanioła i bł. Bronisława Markiewicza pozostające pod opieką michalitów, posiada jednolity zespół witraży z nieco późniejszego okresu. $\mathrm{O}$ witrażach w trzecim obiekcie sakralnym w tej miejscowości, kaplicy Michalitek, brak informacji.

${ }^{64}$ Zapewne w kościele parafialnym pw. Świętych Apostołów Piotra i Pawła w Krępie Kościelnej.

${ }^{65}$ Zapewne w miejscowym kościele parafialnym pw. Najświętszego Serca Pana Jezusa.

${ }^{66} \mathrm{~W}$ kościele pw. św. Józefa.

${ }^{67}$ Zapewne w miejscowym kościele parafialnym pw. św. Bartłomieja.

${ }^{68}$ Niezwykle cenne, gotyckie witraże w krakowskim kościele Dominikanów zostały wymontowane w roku 1915 w związku z oblężeniem Krakowa przez armię rosyjską; ich konserwację zakład S. G. Żeleński podjął w roku 1948, jednak i wówczas nie osadzono ich w miejscu pierwotnej lokalizacji. Zob. Laskowski, Witraże jako przedmiot zainteresowania ..., dz. cyt., s. 110. Por. H. Pieńkowska, Konserwacja witraży dominikańskich w Krakowie, „Ochrona Zabytków” 2 (1949) 3 (7), s. 182-189.

${ }^{69}$ Por. przyp. 63. O miejscu i charakterze prac w Zduńskiej Woli i Łodzi nic nie wiadomo.

${ }^{70}$ Wiadomo było dotychczas, iż w roku 1950 przeprowadzono tu poważne prace renowacyjne (zob. A. Laskowski, Witraże w kościołach diecezji rzeszowskiej w świetle ankiety przeprowadzonej w 1999 roku, „Rzeszowska Teka Konserwatorska” t. 2, 2000, s. 383). Informacja o konserwacji tutejszych witraży w 1950 roku umieszczona jest na witrażu z wizerunkiem św. Jana Ewangelisty. Inny, z herbem papieskim, również posiada tę datę. Dawna tablica informacyjna z opisem przekształceń świątyni znajdująca się przy kościele informuje, iż prace te prowadzono w roku 1949 i 1950, co 
Warto jeszcze pokusić się o porównanie papieru firmowego tego zakładu, zachowanego w liczbie 7 sztuk (plus zbliżony, jeśli chodzi o treść nagłówka, 1 egzemplarz firmowego rachunku) $\mathrm{w}$ archiwum parafialnym w Mszance, stosowanego w roku 1949 (il. 24), z reprodukowanym, bardzo podobnym w swej formie i treści papierem firmowym zakładu użytym przezeń latem $1937 \mathrm{roku}^{71}$. Zaobserwowane różnice dotyczą: zmiany numeru telefonu, zmiany banku $\mathrm{i}$ - w konsekwencji - numeru rachunku bankowego (z Banku Hipotecznego w Krakowie na Komunalną Kasę Oszczędności Powiatu Krakowskiego, a w przypadku pisma z 18 czerwca na Bank Związku Spółek Zarobkowych Oddział w Krakowie ${ }^{72}$ ), usunięcia z oferty sformułowania: „PROJEKTY I KOSZTORYSY BEZPŁATNIE" (zmiana bodaj najbardziej znamienna!) oraz drobnej zmiany kompozycyjnej w układzie liter. Wszystkie inne elementy, w tym bardzo bogata treść oferty zakładu ${ }^{73}$, pozostały bez zmian. Zaobserwowane różnice są niewątpliwie konsekwencją zmian ustrojowych w Polsce i diametralnie zmienionych realiów życia społeczno-gospodarczego.

Porównując zakłady Romańczyka i Żeleńskiego na tle zleceń z Mszanki, można pokusić się o pewne wnioski. Sposób działania obu zakładów, chociaż dotyczył w zasadzie dwóch różnych epok, był porównywalny, i nowe realia powojenne nie miały nań większego wpływu. Pojawiły się za to trudności materiałowe, czego najlepszym przykładem była opisana sprawa pokostu niezbędnego Żeleńskiemu do napraw. Nieco inne były za to, jak się wydaje, standardy stosowane w obu zakładach. Firmę S. G. Żeleński reprezentował w korespondencji konsekwentnie Adam Żeleński, związany formalnie z zakładem od 1929 roku, wspierający matkę w kierowaniu nim, a de facto będący jego główną postacią, zwłaszcza w ostatnich latach funkcjonowania firmy pod zarządem prywatnym. Taka forma korespondencji potwierdza sygnalizowane wielokrotnie w literaturze silne osobiste zaangażowanie

w świetle danych odnalezionych w Mszance wydaje się datowaniem najwłaściwszym. Warto dodać, iż proboszczem był wówczas w Nowym Żmigrodzie ks. Władysław Findysz (1907-1964), 19 czerwca 2005 roku ogłoszony błogosławionym, męczennikiem za wiarę.

${ }^{71}$ Por. D. Czapczyńska-Kleszczyńska, Teodor Andrzej Zajdzikowski (1840-1907), dz. cyt., s. 55, il. 8.

${ }^{72}$ Wydaje się, iż w owym czasie to właśnie ten bank obsługiwał konto firmy Żeleńskich, bowiem jego nazwę podaje w treści swego listu (w celu wpłacenia zaliczki) Żeleński - por. APM, pismo z 22 czerwca 1949.

${ }^{73}$ Mamy tu: rok założenia firmy (1902, a więc liczony od momentu powstania zakładu Władysława Ekielskiego i Antoniego Tucha, przejętego po kilku latach działalności przez S. G. Żeleńskiego), jej oficjalną nazwę, adres i logo oraz (w pionowej kolumnie po lewej stronie) informacje o wykonywaniu według projektów własnych i nadesłanych różnorodnych wyrobów dla świątyń, budynków publicznych, lokali gastronomicznych i budynków mieszkalnych, a to: oszkleń, witraży, mozaik, lamp i latarni. Uzupełniały to zapewnienia o znakomitych referencjach, spis otrzymanych odznaczeń na wystawach (podano wyłącznie grand prix - 3 i złote medale - 15) oraz (u dołu druku) spis katedr, w których znalazły się witraże wykonane w zakładzie. Zaskakująca jest informacja o witrażach zakładu w katedrze w Tarnowie, których dzisiaj tam już nie ma. 
Adama Żeleńskiego w sprawy zakładu i szacunek okazywany klientom. Zabrakło tego w zakładzie Romańczyka, w którym żadne z omówionych pism nie posiadało sygnatury właściciela, gdyż korespondencja prowadzona była przez nieznaną nam, wyznaczoną przez niego osobę.

Przebadane materiały przynoszą nam również informacje o szeregowych pracownikach, którzy w obu firmach zajmowali się montażem bądź naprawą witraży: Ludwiku Olejarzu z zakładu Romańczyka oraz Władysławie Jaworskim i Mieczysławie Widle z zakładu S. G. Żeleński. W pierwszym przypadku jest to wiadomość o tyle cenna, że - w połączeniu z osobą prowadzącą korespondencję pracowni - wskazuje jednoznacznie na wieloosobowy skład zespołu zatrudnionego w firmie Romańczyka.

Ciekawy jest sposób, w jaki Adam Żeleński ocenił realizację Romańczyka w obliczu pęknięcia oryginalnych szkieł przy naprawie. Uczynił to jak prawdziwy znawca, bez złych emocji: „najwyraźniej szkła były albo całkiem niehartowane, albo źle hartowane, a ponieważ w ołowiach brak było kitówki, więc gdy dziś został kit wprowadzony - schnąc rozerwał te liche szkła. [...] i to jest winą pierwszego ich wykonawcy tj. właśnie p. Romańczyka"74.

Sprawa witraży do kościoła w podgorlickiej Mszance, z pozoru mało interesująca z uwagi na niezbyt wysoki poziom artystyczny samych dzieł oraz ich obiegowy charakter, została opracowana po to, aby pokazać, iż z dziełami takimi może być związany cały szereg ważnych dla badacza sztuki witrażowej kwestii, poczynając od kulisów funkcjonowania firm witrażowych w różnych okresach historycznych i stosowanych przez nie zabiegów w stosunku do klienta, poprzez postawy właścicieli zakładów witrażowych względem własnej firmy, aż po nieznany dotychczas z innych źródeł, rzeczywisty i wiarygodnie udokumentowany dorobek firm.

Witraże w Mszance, mało ambitne w sensie artystycznym, w konfrontacji z materiałem źródłowym w istotny sposób poszerzają naszą wiedzę o sztuce witrażowej w Polsce w 2. ćwierci XX wieku, pokazując zarazem, ile wątków badawczych wywołać może jeden skromny zespół witrażowy i jak wiele jest wciąż do zrobienia w tym względzie. Droga do rzetelnej syntezy dziejów sztuki witrażowej w Polsce jest wciąż długa, wiedzie przez wiele małych wsi, miast i miasteczek z ich kościołami, plebaniami, budynkami użyteczności publicznej czy kamienicami. Nawet jeśli nie tam rozstrzygały się zasadnicze kwestie, to właśnie tam drzemie największy potencjał materiałowy i faktograficzny, mogący znacząco stan naszej wiedzy uzupełnić, jeśli nie zmienić.

${ }^{74}$ APM, pismo z 20 sierpnia 1949. 


\section{Summary}

\section{The stained glass in the parish church in Mszanka near Gorlice. Contribution to the study of Kraków stained glass art from the second quarter of the $20^{\text {th }}$ century}

Windows in the parish church of the Holy Apostles Peter and Paul in Mszanka near Gorlice, which supplements the architecture of the church built in 1938-1940 following the design of Edward Okon, an architect from Tarnów, comprises 12 stained glass: two figural in the chancel, eight geometrical with medallions in the nave and transept, and two with monograms on both sides of the main entrance. Although plain in the artistic sense, and in the case of the figural ones - mediocre, these stained glass successfully complement the bright and orderly interior of the parish church. The inscriptions on two panels and existing archival sources inform us that the windows were created in 1938 in the Kraków workshop of Maksymilian Romańczyk. The archival documents describe the entire investment process leading to their creation and their repair which was necessary due to their deficient construction. This task was undertaken in 1949 by the renowned Kraków Stained Glass Company S. G. Żeleński, which is also described in detail in the historical records.

Stained glass and primarily the archival materials preserved in Mszanka are excellent sources of many valuable details on stained glass workmanship in Poland in the second quarter of the $20^{\text {th }}$ century, the division of tasks within stained glass workshops, the involvement of the clients, and on projects that the above-mentioned workshops were working on concurrently at that time - information which was previously unknown. In turn, the preserved company letterhead authorised with the original stamps provides useful information on the functioning of these types of workshops, their products and achievements. In quite a distinct manner, the letterhead also tells us a little about the history of the workshops.

The above example confirms that works of art or archival material stored until this day in locations outside urban areas can valuably supplement and sometimes even alter our knowledge of stained glass art in Poland.

\section{Keywords}

Stained glass art, 20th-century art, Jan Kusiak, Maksymilian Romańczyk, Teodor Zajdzikowski, S. G. Żeleński, Kraków 


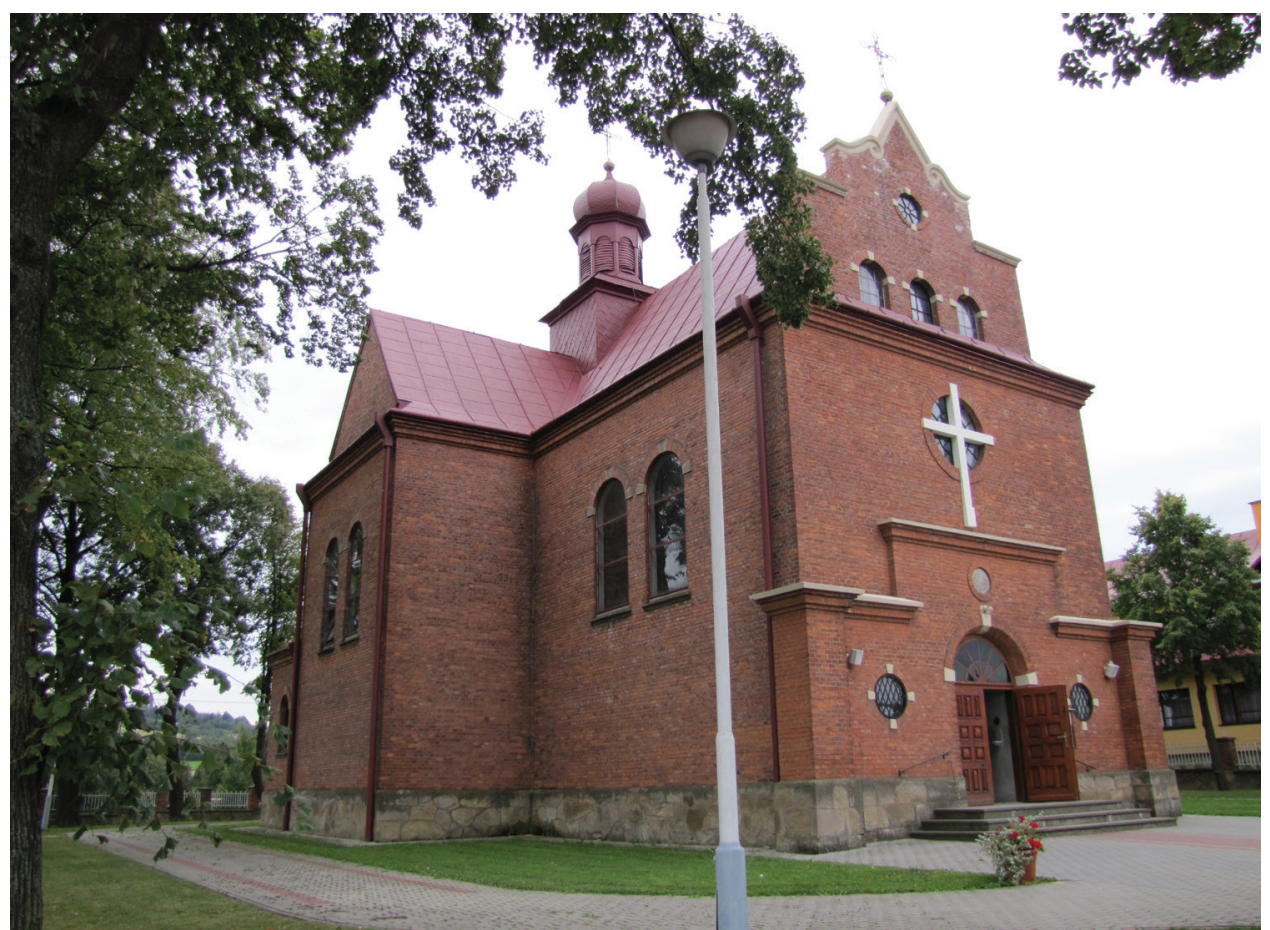

il. 1. Kościół pw. Świętych Apostołów Piotra i Pawła w Mszance. Widok ogólny. Fot. A. Laskowski, 2010

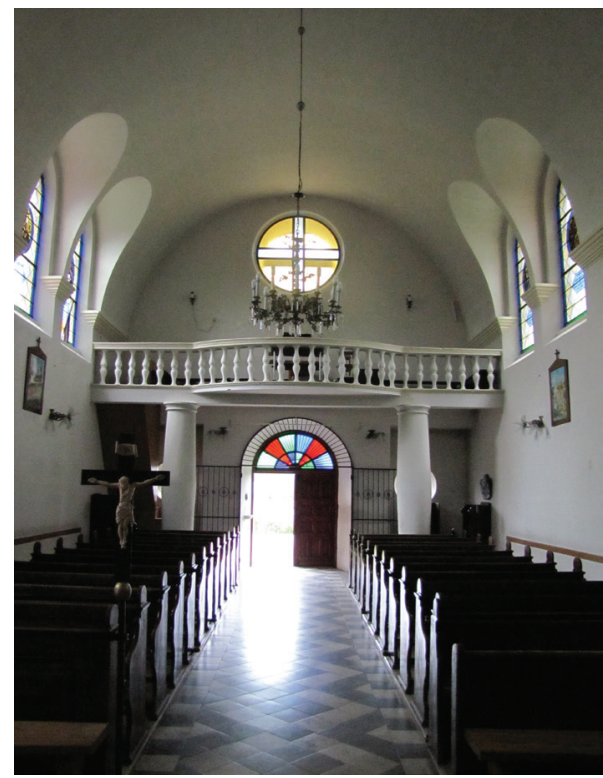

il. 2. Kościół pw. Świętych Apostołów Piotra i Pawła w Mszance. Wnętrze korpusu nawowego - widok w stronę chóru muzycznego. Fot. A. Laskowski, 2010

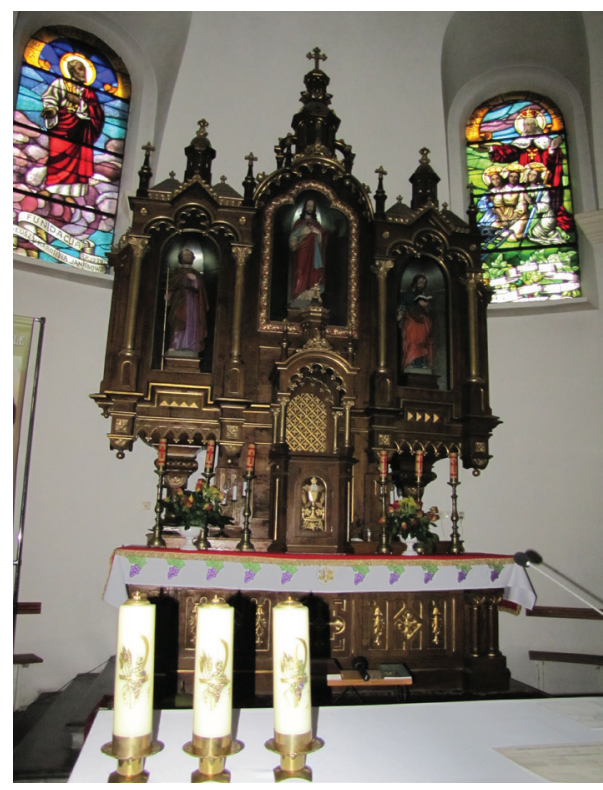

il. 2. Kościół pw. Świętych Apostołów Piotra i Pawła w Mszance. Wnętrze korpusu nawowego - widok w stronę chóru muzycznego. Fot. A. Laskowski, 2010 


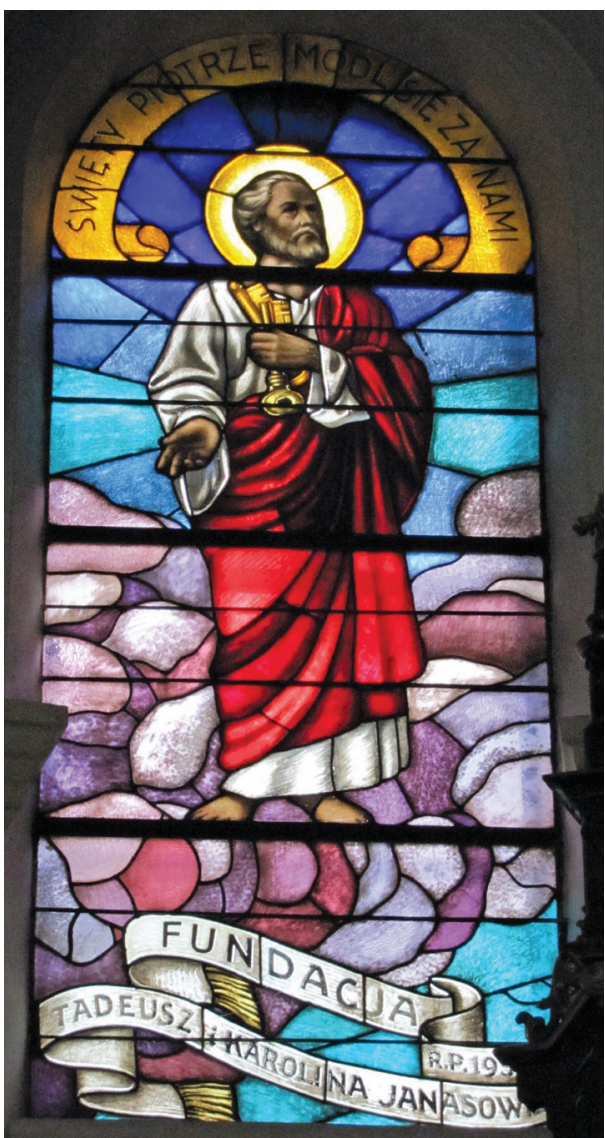

il. 4. Kościół pw. Świętych Apostołów Piotra i Pawła w Mszance. Witraż ze św. Piotrem w prezbiterium.

Fot. A. Laskowski, 2010

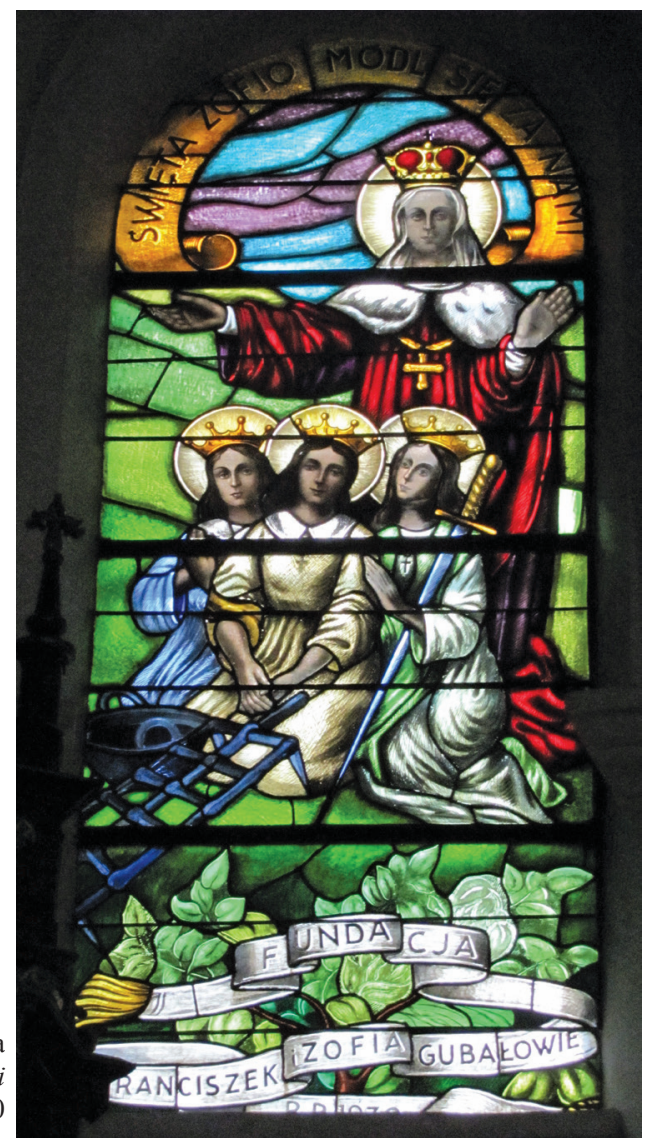

w Mszance. Witraż Św. Zofia z trzema córkami w prezbiterium. Fot. A. Laskowski, 2010 


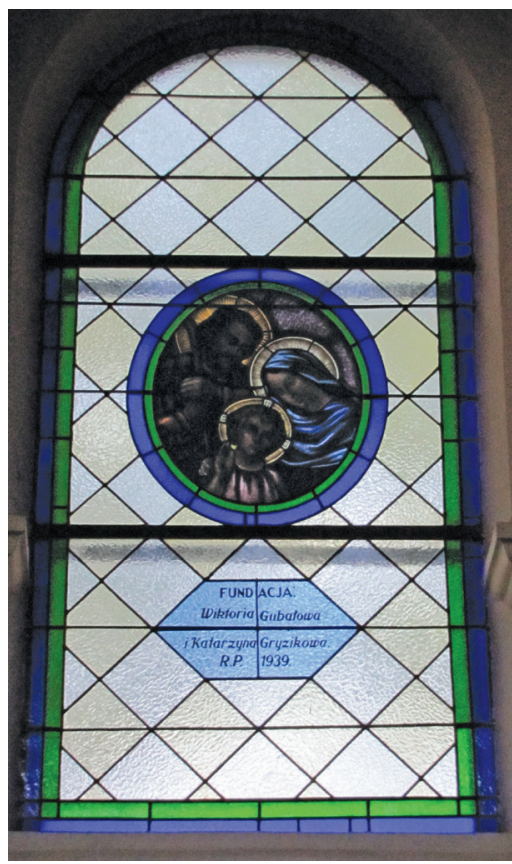

il. 6. Kościół pw. Świętych Apostołów Piotra i Pawła w Mszance. Witraż Św. Rodzina w korpusie nawowym. Fot. A. Laskowski, 2011

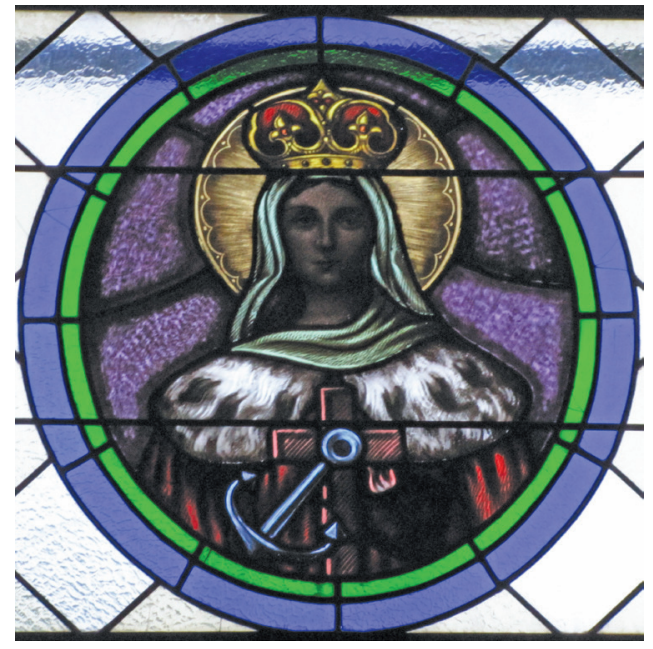

il. 7. Kościół pw. Świętych Apostołów Piotra i Pawła w Mszance. Fragment witraża Św. Zofia w korpusie nawowym. Fot. A. Laskowski, 2011

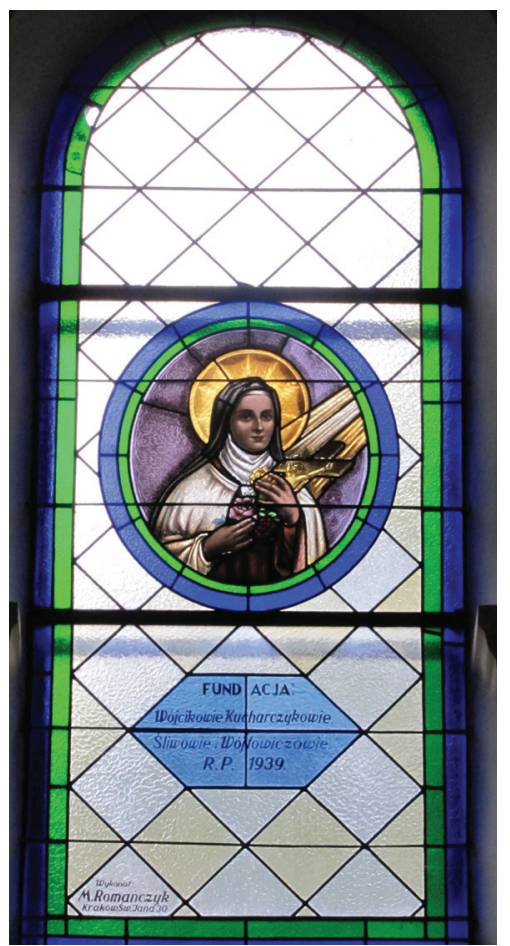

il. 8. Kościół pw. Świętych Apostołów Piotra i Pawła w Mszance. Witraż Św. Teresa w transepcie. Fot. A. Laskowski, 2010 w Mszance. Fragment witraża Serce Marii w transepcie. Fot. A. Laskowski, 2010 il. 9. Kościół pw. Świętych Apostołów Piotra i Pawła

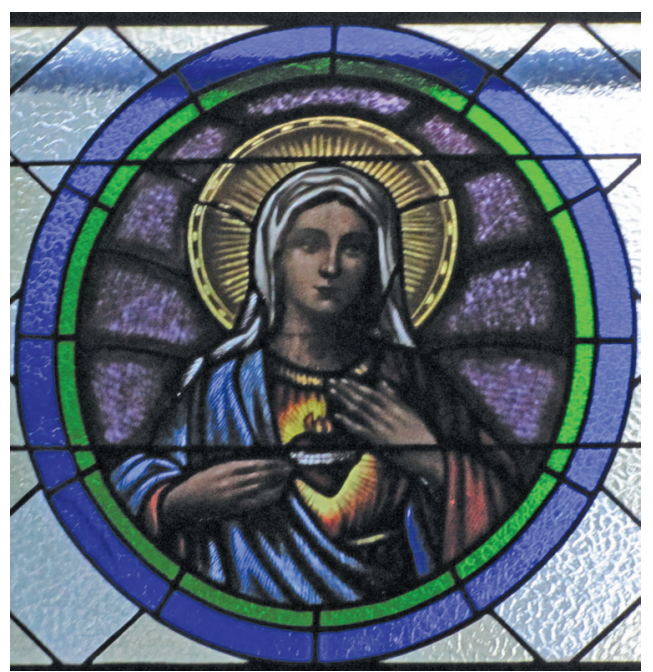




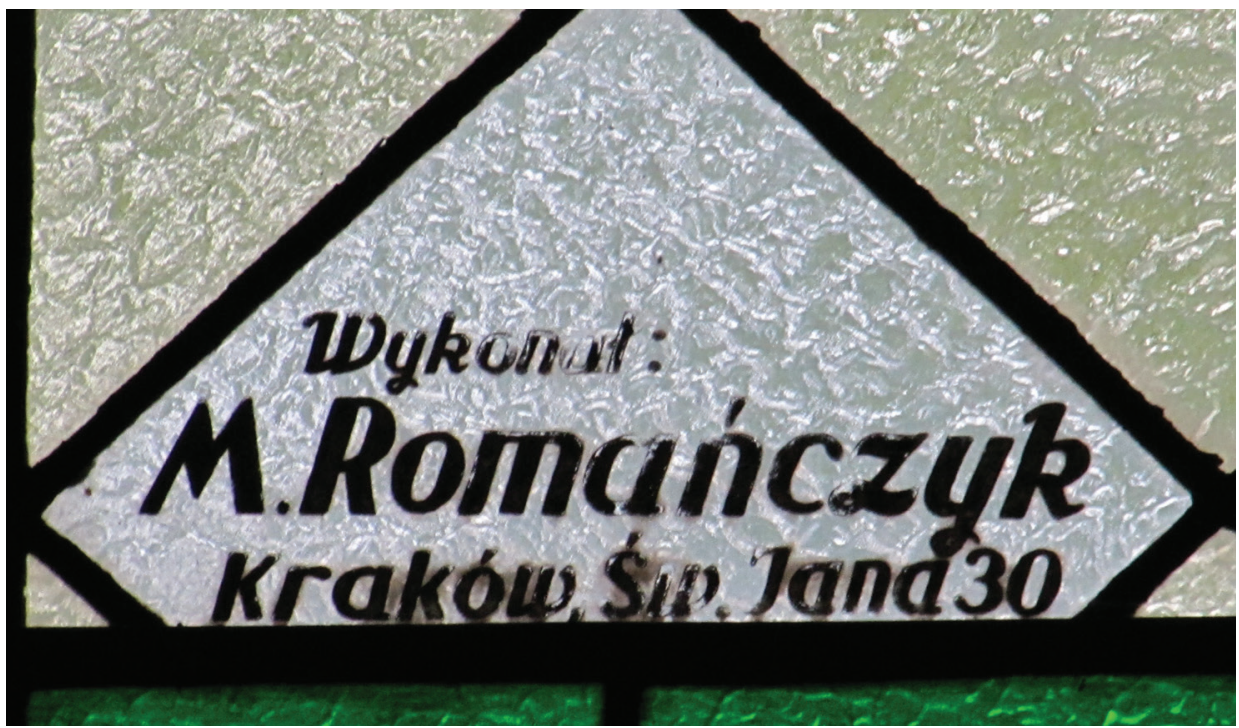

il. 10. Kościół pw. Świętych Apostołów Piotra i Pawła w Mszance. Sygnatura zakładu Maksymiliana Romańczyka na witrażu ze św. Stanisławem Kostką. Fot. A. Laskowski, 2011

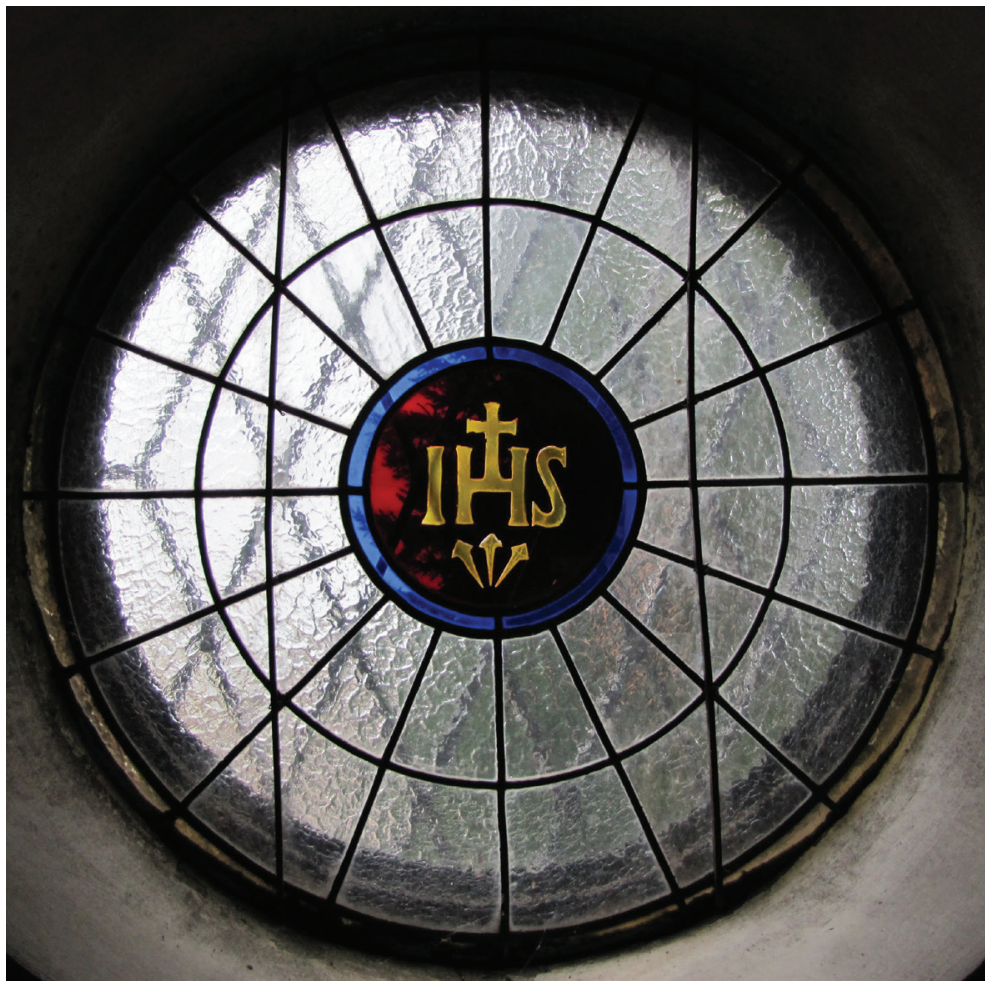

il. 11. Kościół pw.

Świętych Apostołów

Piotra i Pawła

w Mszance. Witraż

$\mathrm{z}$ monogramem

IHS pod chórem

muzycznym.

Fot. A. Laskowski, 2010 


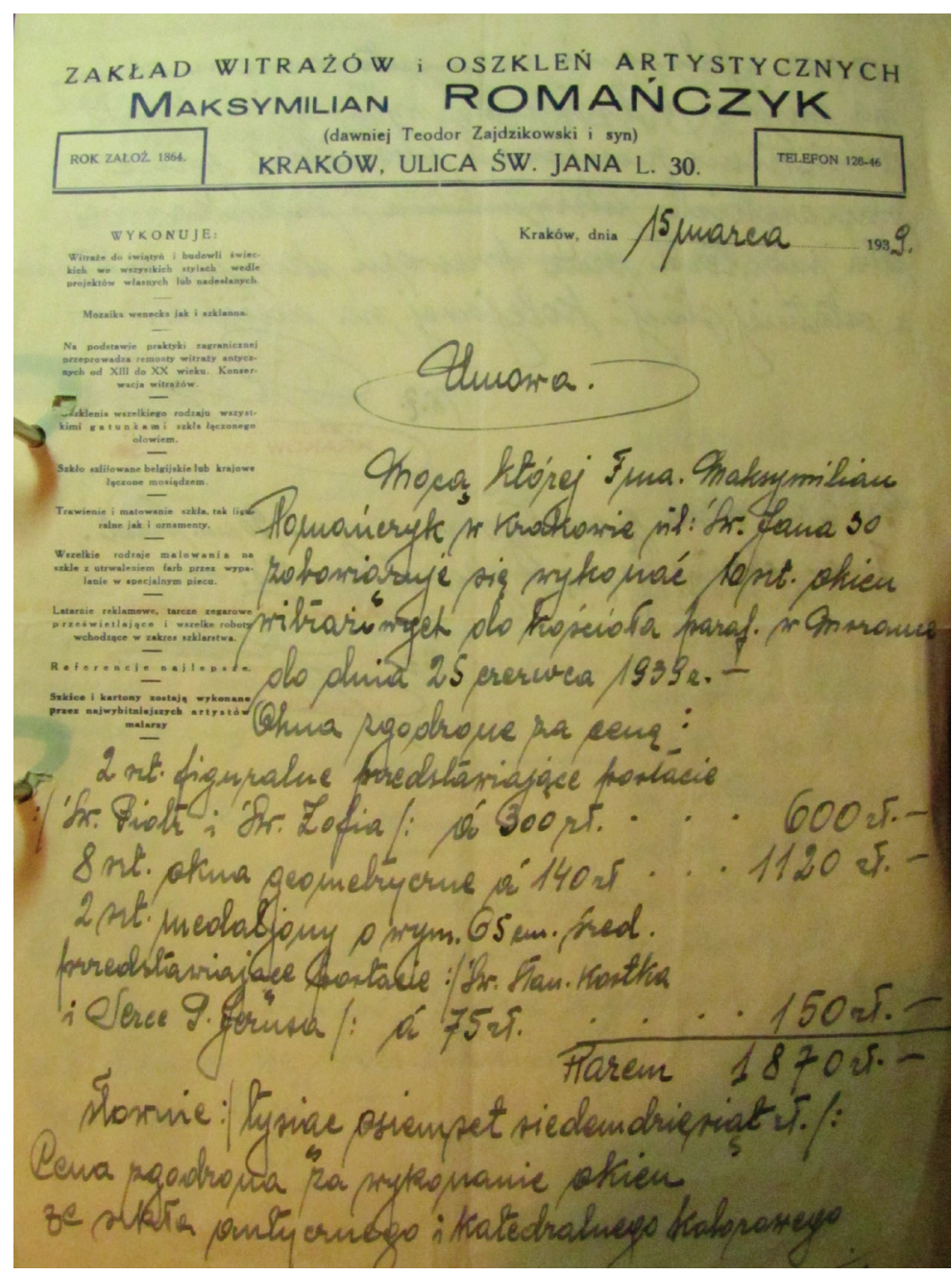

il. 12. Papier firmowy zakładu Maksymiliana Romańczyka $\mathrm{z}$ umowa na wykonanie witraży do kościoła w Mszance z dnia 15 marca 1939 roku.

Fot. A. Laskowski, 2011

il. 13. Pieczątka zakładu Maksymiliana Romańczyka na piśmie z 24 lutego 1939 roku. Fot. A. Laskowski, 2011

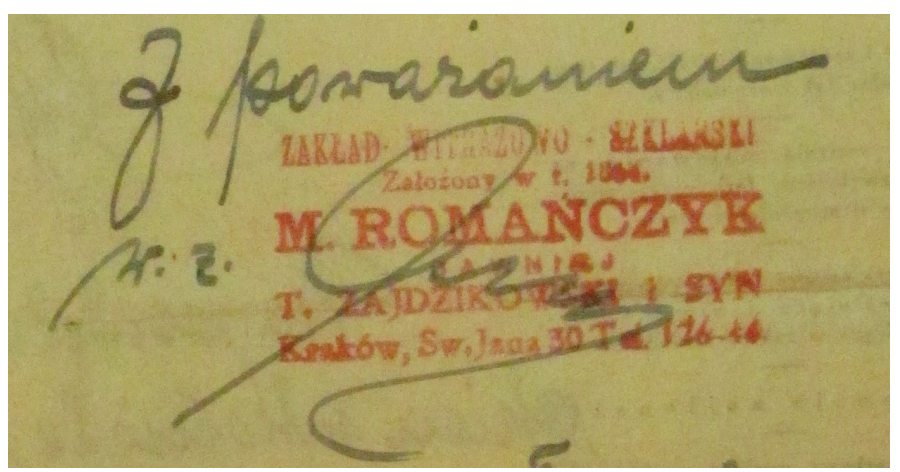




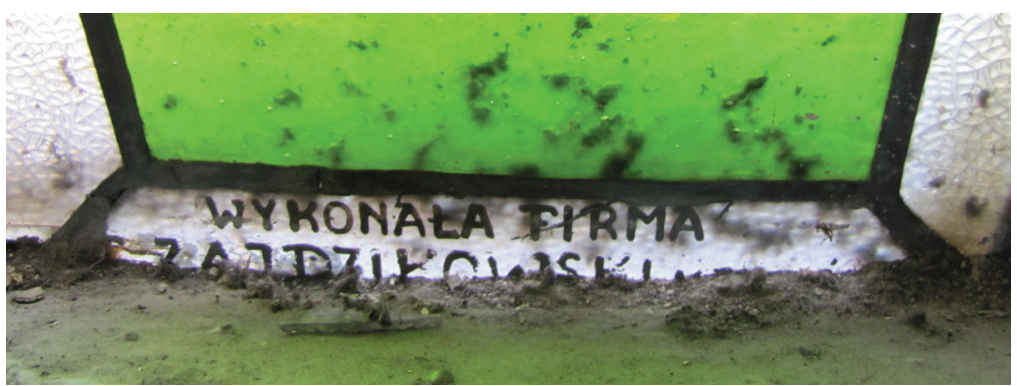

il. 15. Częściowo zamurowana sygnatura zakładu Zajdzikowskiego na jednym $\mathrm{z}$ witraży nawy kościoła parafialnego pw. św. Józefa Oblubieńca NMP w Bystrej. Fot. A. Laskowski, 2011
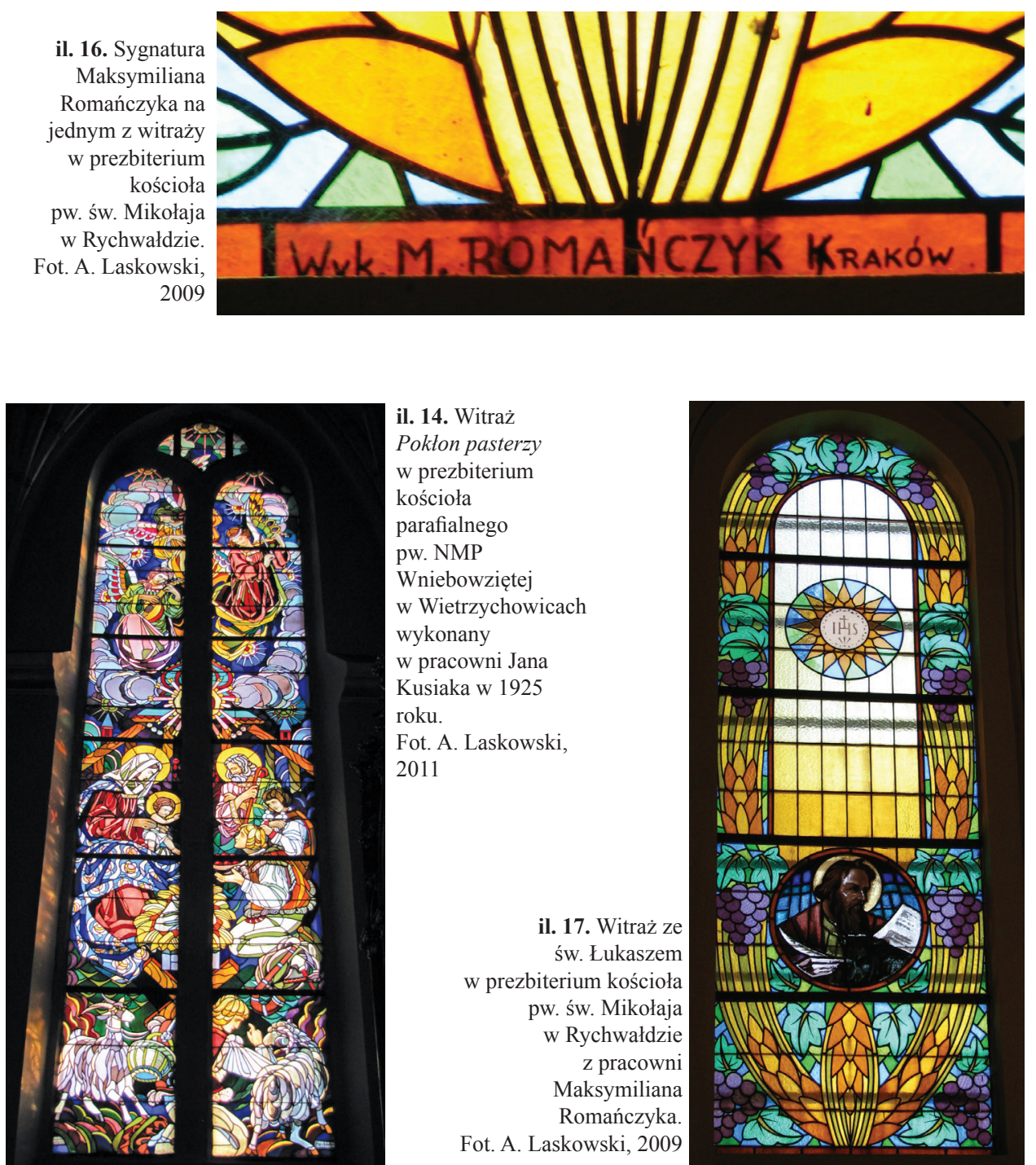

il. 14. Witraż

Pokłon pasterzy

w prezbiterium

kościoła

parafialnego

pw. NMP

Wniebowziętej

w Wietrzychowicach

wykonany

w pracowni Jana

Kusiaka w 1925

roku.

Fot. A. Laskowski,

2011

il. 17. Witraż ze

św. Łukaszem

w prezbiterium kościoła

pw. św. Mikołaja w Rychwałdzie z pracowni

Maksymiliana

Romańczyka.

Fot. A. Laskowski, 2009

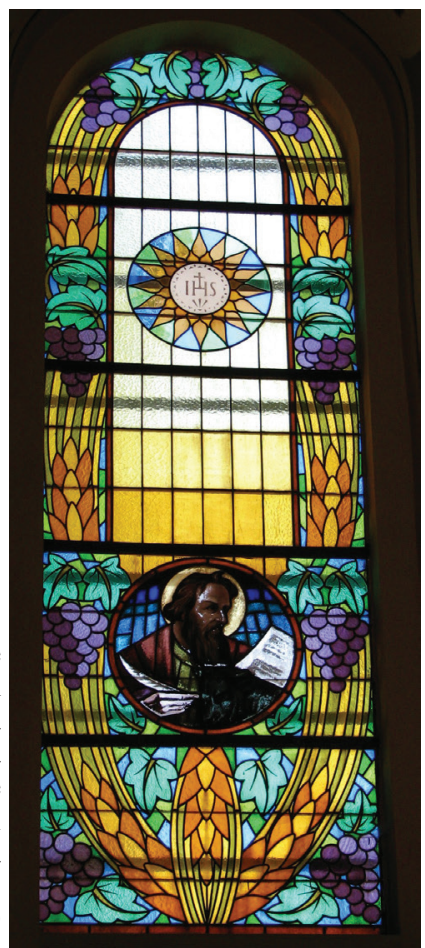




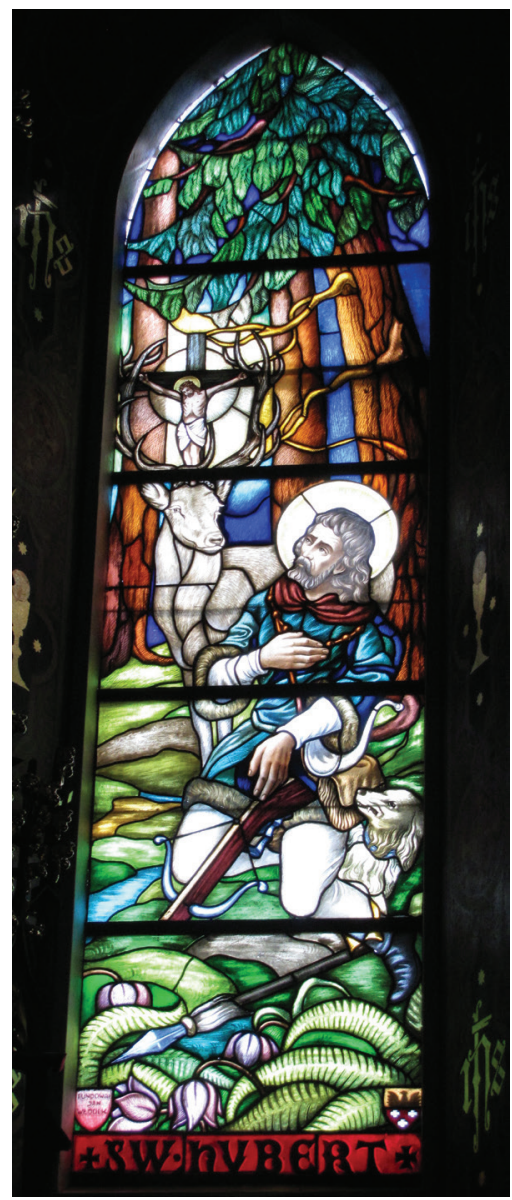

il. 19. Witraż fundacji Jana Włodka w kościele parafialnym pw. Wniebowzięcia NMP w Ostrowach Tuszowskich, wykonany w roku 1939 przez zakład Maksymiliana Romańczyka.

Fot. A. Laskowski, 2011

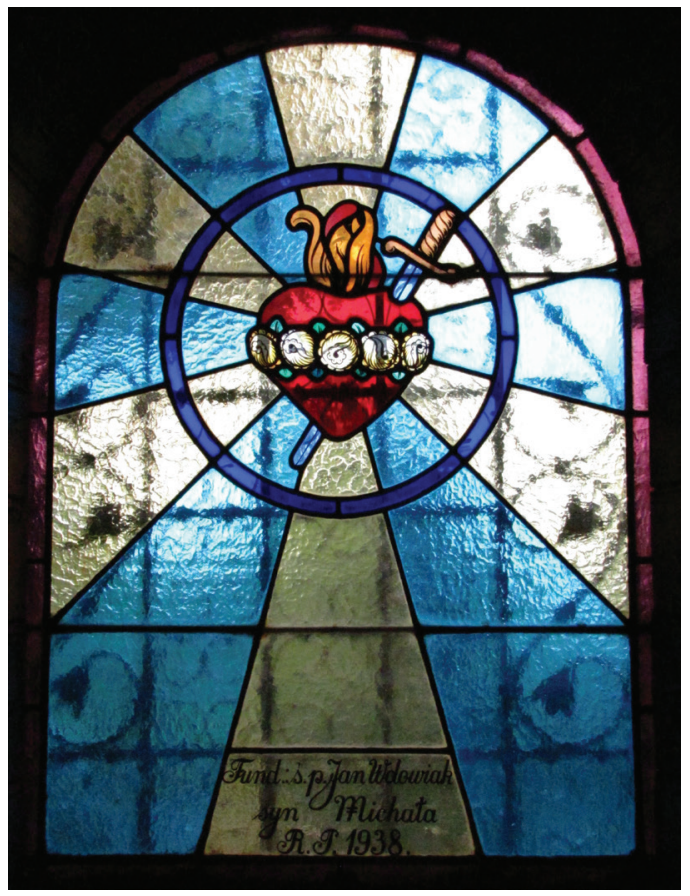

il. 18. Witraż z 1938 roku z pracowni Maksymiliana Romańczyka w kościele parafialnym pw. św. Zygmunta w Żelichowie. Fot. A. Laskowski, 2011

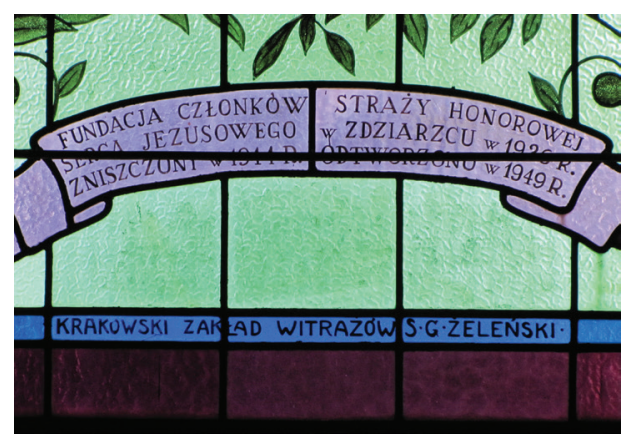

il. 21. Fragment witraża $z$ informacją o jego odtworzeniu w 1949 roku przez zakład S. G. Żeleński w prezbiterium kościoła parafialnego pw. Nawiedzenia NMP w Zdziarcu. Fot. A. Laskowski, 2011

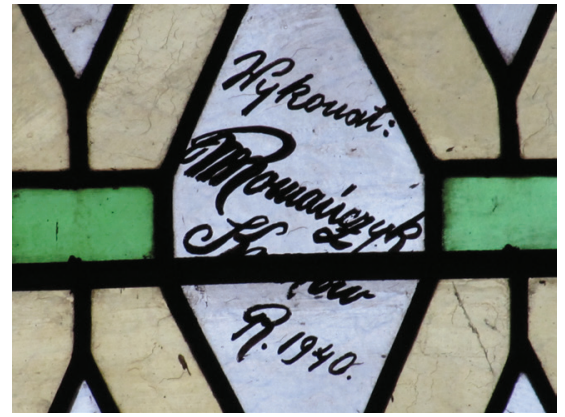

il. 20. Sygnatura Maksymiliana Romańczyka z 1940 roku na ornamentalnej partii witraża w korpusie nawowym kościoła parafialnego pw. NMP Wniebowziętej w Wietrzychowicach. Fot. A. Laskowski, 2011 


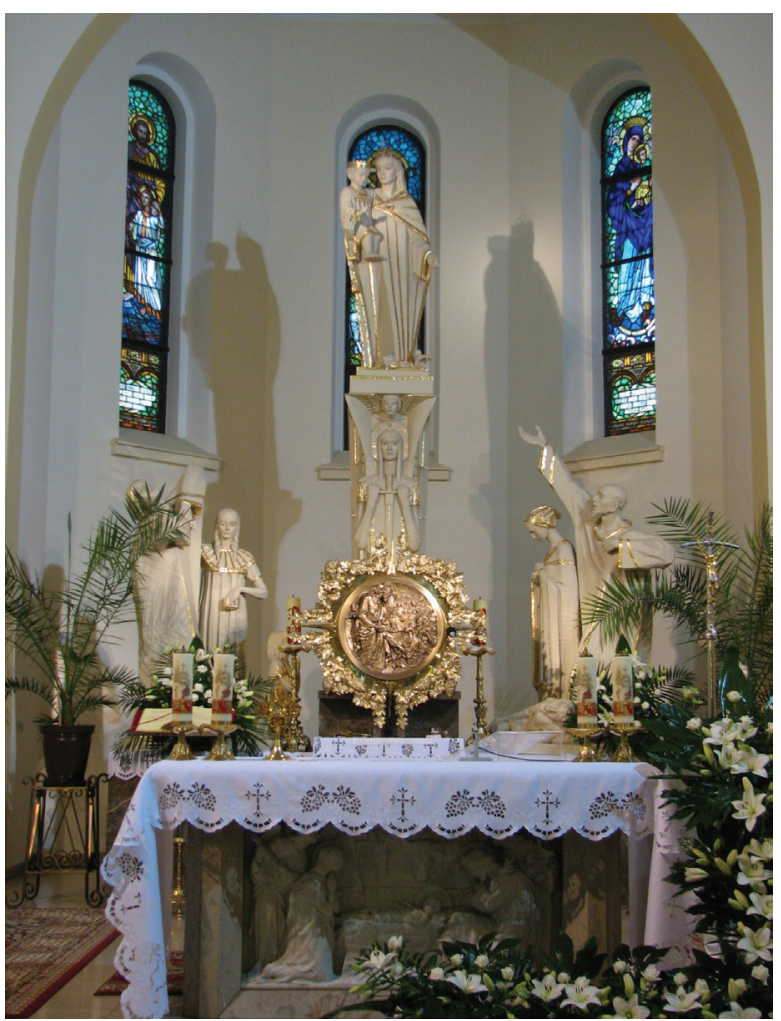

il. 22. Zamknięcie prezbiterium kościoła parafialnego pw. Wszystkich Świętych i Niepokalanego Serca NMP w Straszęcinie, w którego oknach umieszczono witraże z 1949 roku wykonane w zakładzie S. G. Żeleński. Fot. A. Laskowski, 2009

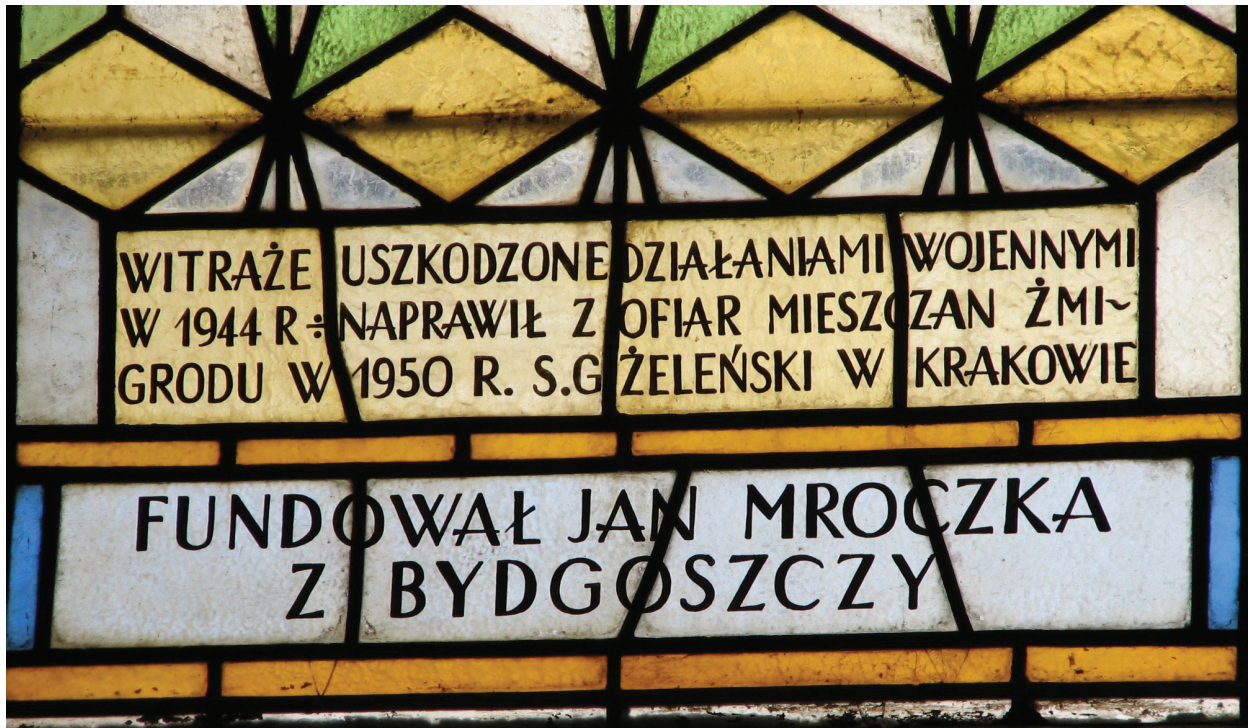

il. 23. Fragment jednego z witraży w kościele parafialnym pw. Świętych Apostołów Piotra i Pawła w Nowym Żmigrodzie z informacją o naprawach przeprowadzonych tu przez zakład S. G. Żeleński. Fot. A. Laskowski, 2009 


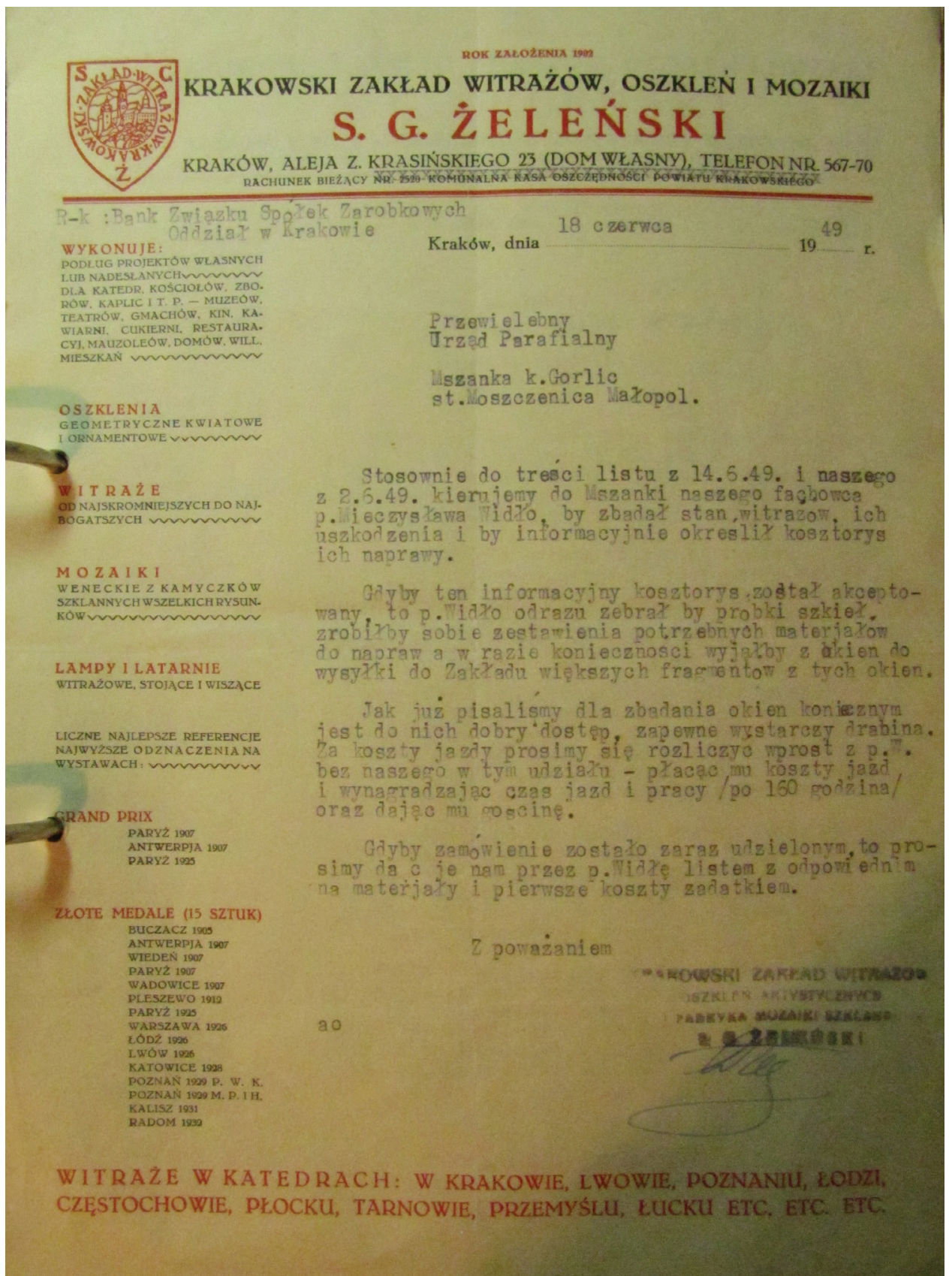

il. 24. Papier firmowy zakładu S. G. Żeleński - pismo z 18 czerwca 1949 roku. Fot. A. Laskowski, 2011 
